\title{
65 YEARS OF THE DOUBLE HELIX Genetics informs precision practice in the diagnosis and management of pheochromocytoma
}

\author{
Hartmut P Neumann', William F Young Jr², Tobias Krauss³, Jean-Pierre Bayley4, Francesca Schiavi5, \\ Giuseppe Opocher5, Carsten C Boedeker6, Amit Tirosh7, Frederic Castinetti,8, Juri Ruf10, Dmitry Beltsevich"1, \\ Martin Walz'12, Harald-Thomas Groeben ${ }^{13}$, Ernst von Dobschuetz'14, Oliver Gimm ${ }^{15,16}$, Nelson Wohllk ${ }^{17}$, \\ Marija Pfeifer ${ }^{18}$, Delmar M Lourenço Jr19, Mariola Peczkowska20, Attila Patocs²1, Joanne Ngeow², Özer Makay23, \\ Nalini S Shah24, Arthur Tischler25, Helena Leijon26, Gianmaria Pennelli27, Karina Villar Gómez de las Heras², \\ Thera P Links ${ }^{29}$, Birke Bausch ${ }^{30}$ and Charis Eng ${ }^{31}$
}

1Section for Preventive Medicine, University Medical Center, Albert-Ludwigs-University, Freiburg, Germany 2Division of Endocrinology, Diabetes, Metabolism, and Nutrition, Mayo Clinic, Rochester, New York, USA ${ }^{3}$ Department of Radiology, Medical Center - University of Freiburg, Faculty of Medicine, University of Freiburg, Freiburg, Germany ${ }^{4}$ Department of Human Genetics, Leiden University Medical Center, Leiden, The Netherlands 5Familial Cancer Clinic and Oncoendocrinology, Veneto Institute of Oncology, IRCCS, Padova, Italy ${ }^{6}$ Department of Otorhinolaryngology, HELIOS Hanseklinikum Stralsund, Stralsund, Germany

${ }^{7}$ Sackler Faculty of Medicine, Tel Aviv University, Tel Aviv, Israel

8Department of Endocrinology, Aix-Marseille Université, Institut National de la Santé et de la Recherche Médicale (INSERM), U1251, Marseille Medical Genetics (MMG), Marseille, France

${ }^{9}$ Assistance Publique - Hôpitaux de Marseille (AP-HM), Hôpital de la Conception, Centre de Référence des Maladies Rares Hypophysaires HYPO, Marseille, France

${ }^{10}$ Department of Nuclear Medicine, Faculty of Medicine, Albert-Ludwigs-University, Freiburg, Germany

${ }_{11}$ Department of Surgery, Endocrinology Research Center, Moscow, Russia

${ }^{12}$ Department of Surgery and Center of Minimally-Invasive Surgery, Kliniken Essen-Mitte, Essen, Germany ${ }^{13}$ Department of Anesthesiology, Kliniken Essen-Mitte, Essen, Germany

${ }^{14}$ Section of Endocrine Surgery, Clinic of General, Visceral and Thoracic Surgery, Krankenhaus Reinbek, Academic Teaching Hospital University of Hamburg, Reinbek, Germany

${ }^{15}$ Department of Clinical and Experimental Medicine, Faculty of Health Sciences, Linköping University, Linköping, Sweden

${ }^{16}$ Department of Surgery, Region Östergötland, Linköping, Sweden

${ }^{17}$ Endocrine Section, Universidad de Chile, Hospital del Salvador, Santiago de Chile, Chile

18Department of Endocrinology, University Medical Center Ljubljana, Ljubljana, Slovenia

${ }^{19}$ Endocrine Genetics Unit, Endocrinology Division, Hospital das Clínicas, University of São Paulo School of Medicine (FMUSP), Endocrine Oncology Division, Institute of Cancer of the State of São Paulo, FMUSP, São Paulo, Brazil

20Department of Hypertension, Institute of Cardiology, Warsaw, Poland

${ }^{21}$ HSA-SE 'Lendület' Hereditary Endocrine Tumor Research Group, Hungarian Academy of Sciences and Semmelweis University, Budapest, Hungary ${ }^{22}$ Lee Kong Chian School of Medicine, Nanyang Technological University Singapore and Cancer Genetics Service, National Cancer Centre Singapore, Singapore, Singapore

${ }^{23}$ Division of Endocrine Surgery, Department of General Surgery, Ege University, Izmir, Turkey

${ }^{24}$ Department of Endocrinology, Seth G S Medical College, K.E.M. Hospital, Parel, Mumbai, India

${ }^{25}$ Department of Pathology and Laboratory Medicine, Tufts Medical Center and Tufts University School of Medicine, Boston, Massachusetts, USA

${ }^{26}$ Department of Pathology, University of Helsinki, and HUSLAB, Helsinki University Hospital, Helsinki, Finland

27Department of Medicine (DIMED), Surgical Pathology Unit, University of Padua, Padua, Italy

${ }^{28}$ Central Services, Servicio de Salud de Castilla-La Mancha (SESCAM), Toledo, Spain

29Department of Endocrinology, University of Groningen, University Medical Center Groningen, Groningen, The Netherlands

30Department of Medicine II, Medical Center - University of Freiburg, Faculty of Medicine, University of Freiburg, Freiburg, Germany

${ }^{31}$ Genomic Medicine Institute, Lerner Research Institute and Taussig Cancer Institute, Cleveland Clinic, Cleveland, Ohio, USA

Correspondence should be addressed to B Bausch: birke.bausch@uniklinik-freiburg.de

Paper is part of a thematic review section celebrating 65 Years of the Double Helix. The guest editors for this section were Charis Eng, William Foulkes and Jérôme Bertherat. C Eng was not involved in the review or editorial process for this paper, on which she is listed as an author. 


\section{Abstract}

Although the authors of the present review have contributed to genetic discoveries in the field of pheochromocytoma research, we can legitimately ask whether these advances have led to improvements in the diagnosis and management of patients with pheochromocytoma. The answer to this question is an emphatic Yes! In the field of molecular genetics, the well-established axiom that familial (genetic) pheochromocytoma

\section{Key Words}

- brown adipose tissue

- white adipose tissue

- lipid metabolism

oxidative stress represents $10 \%$ of all cases has been overturned, with $>35 \%$ of cases now attributable to germline disease-causing mutations. Furthermore, genetic pheochromocytoma can now be grouped into five different clinical presentation types in the context of the ten known susceptibility genes for pheochromocytoma-associated syndromes. We now have the tools to diagnose patients with genetic pheochromocytoma, identify germline mutation carriers and to offer gene-informed medical management including enhanced surveillance and prevention. Clinically, we now treat an entire family of tumors of the paraganglia, with the exact phenotype varying by specific gene. In terms of detection and classification, simultaneous advances in biochemical detection and imaging localization have taken place, and the histopathology of the paraganglioma tumor family has been revised by immunohistochemical-genetic classification by gene-specific antibody immunohistochemistry. Treatment options have also been substantially enriched by the application of minimally invasive and adrenal-sparing surgery. Finally and most importantly, it is now widely recognized that patients with genetic pheochromocytoma/ paraganglioma syndromes should be treated in specialized centers dedicated to the diagnosis, treatment and surveillance of this rare neoplasm.

\section{Introduction}

Over the last two decades, advances in the genetics of pheochromocytoma with the detection of germline (heritable) mutations in many new genes that predispose to this neoplasm and other extra-adrenal paraganglial tumors have led to improved molecular diagnosis, effective predictive testing of as yet unaffected relatives and informed gene-specific medical management.

\section{A personal remembrance by Hartmut Neumann}

I can remember well the publication in Nature in 1985 by Steven Reeders and coworkers (Oxford, UK) that located the gene encoding autosomal dominant polycystic kidney disease (ADPKD) on chromosome 16 using, then still novel, linkage analysis (Reeders et al. 1985). For a nephrologist with a central interest in the causes of disease, to me this was a first glimmer of modern medicine. The next day, in the morning meeting of all branches of the Department of Internal Medicine of the University of Freiburg, I raised my hand and gave a brief report of this exciting discovery. As these morning meetings were exclusively dedicated to newly admitted patients, such scientific news was never announced and my colleagues surely thought they had another 'addled' member.

I had joined the Department of Internal Medicine 2 years prior to that fateful morning, after a 5-year training program in pathology, with the goal of establishing an academic career. In my third week on staff, I was confronted with a patient with pheochromocytoma whose sister reported that her son had surgery for an adrenal pheochromocytoma at age 13 years and contralaterally at age 16 years and that she had herself undergone surgery for cerebellar hemangioblastoma the previous year. Something was clearly amiss in this family and by the next day I could say with confidence, 'You have Von Hippel-Lindau disease (VHL)'. I quickly wrote a case report detailing the family, which unfortunately later 'died' on the desk of an editor-in-chief of a German medical journal. In parallel, I made an appointment for a meeting with the entire VHL family in question, drew blood from affected and unaffected members of three generations and I went to the Institute of Human Genetics in order to persuade these colleagues to find the gene. Unfortunately, they failed to grasp the opportunity to create a new center for mapping the $V H L$ gene. At that time only very few fully 
grasped the concept of mutations in genes associated with disease. It was also not yet known whether genes had a specific structure or how they could be found in an endless sea of DNA. Perhaps understandably, the Freiburg team was not prepared to take on the responsibility of clinical research in an entirely new field of human genetics. Therefore, alone and slightly frustrated, I nevertheless decided to take on this quest myself.

ADPKD was an important clinical challenge, since $20 \%$ of our patients on dialysis and numerous patients in the wards suffered from this disease. ADPKD was now a very attractive disease model because the cause was clear: inheritance. But what role could be played by clinical research? That was, and still is, the principal question. In other words: Cui bono - for whose benefit? In ADPKD, research programs pursued the use of ultrasonography to identify disease in relatives. However, it became immediately clear that in doing so asymptomatic ADPKD would be detected in young women and men. The dilemma that I now faced was that I clearly could not conceal the findings, but how could I answer their questions regarding preventative treatment options and hopes of avoiding the fate of mothers and fathers, which had dominated their family life? Inevitably, given the clinical options at the time, any answers I could provide would undoubtedly precipitate major psychological problems in young, mostly unmarried, women and men. With no good answers in sight and to avoid moral conflicts, I decided to refocus my activities in other directions.

However, in the first inherited pheochromocytoma syndrome that I came across, VHL, the situation was completely different. VHL is characterized by kidney cancer, pheochromocytoma and other neoplasias. Ambitious researchers could easily see the potential benefit for VHL families of early diagnosis in time for curative surgery for pheochromocytomas and other tumors. A lecture by Bruce Ponder from the University of Cambridge, UK at a symposium in Heidelberg also opened new avenues for research of another inherited pheochromocytoma-associated disorder and multiple endocrine neoplasia type 2 (MEN 2) (see review in this issue and MEN 2 anniversary issue). I subsequently visited his group in Cambridge, where I saw the memorable slogan: 'Fight Cancer on All Frontiers'. On my return to Freiburg, I collaborated with the Cambridge group, sending blood samples from patients and families with MEN 2. These mutual efforts resulted in joint publications in the genetics and management of pheochromocytoma, led by Charis Eng, then a postdoctoral fellow with Prof. Ponder (1992-1995) and myself. The mid-1980s saw the birth of the era of gene hunting, which included VHL and MEN 2. During this heady era of human molecular genetics, the heritable endocrine neoplasias and especially pheochromocytoma proved to be beneficiaries.

\section{Terminology and clinical characteristics of tumors of the 'pheochromocytoma family'}

There is, unfortunately, still little consistency and systematic use of terminology and abbreviations for the paraganglia family of tumors. The World Health Organization (WHO) classification reserves the term pheochromocytoma exclusively for tumors of the adrenal medulla (Lloyd et al. 2017). The word pheochromocytoma is of Greek origin, but its usage only dates back to 1912 (Pick 1912). The last syllables cytoma means growing cells or tumor, the middle syllables chromo refer to the former usage of a special chromate-containing stain and pheo refers to the classic brown appearance after exposure to chromate staining (Bausch et al. 2017b). In contrast, paraganglioma is a terminology of pathoanatomy, meaning a tumor of the paraganglia, which are formed by the aggregation of the cell nuclei of the widespread autonomic nervous system, of which the adrenal medulla is the largest. A strict separation of these terms in clinical use as suggested by specialists is sophisticated and best recognized in everyday use of general physician, surgeons, internists and also congress announcements where pheochromocytoma is still used for all such tumors including their symptoms.

A distinct group of these tumors is located in the neck and the skull base. They originate from the parasympathetic paraganglia, mainly the carotid body, but also from the tympanic, jugular, vagal or other paraganglia. All these tumors, for which the abbreviations HNPGL or HNP are used, are mostly asymptomatic due to a lack of catecholamine overproduction and are very rarely metastatic. Only single cases of catecholamineproducing HNPs, mainly of the carotid body, are reported (Niemann et al. 2003, Zeng et al. 2013, Elshafie et al. 2014). Of note, however, virtually all clinicians still use the term pheochromocytoma when speaking of a tumor with symptoms of catecholamine overproduction, including those located outside the adrenal glands (Neumann 2018).

The incidence of pheochromocytoma and HNP based on nearly 1500 patients who were diagnosed and histopathologically confirmed between 1995 and 2015 was 0.04-0.21 per 100,000 person-years (Berends et al. 2018). The incidence increased in the latter years of this study mainly by detection of the tumors in older age and a smaller tumor size at diagnosis. 
Pheochromocytoma is a rare and fascinating tumor, and there is virtually no patient who does not attract special interest. Besides being rare, interesting aspects include the broad spectrum of signs and symptoms, the frequently long delay before diagnosis, and the frequent young age of the patients. Paroxysms of headache, palpitations, tachycardia, profuse sweating and hypertension are the main signs and symptoms; but, the list of clinical presentations is long and also includes metabolic deterioration and psychiatric imbalance with depression or panic attacks (Neumann 2018). Due to the use of genetic testing and the widespread use of computed imaging, an increasing proportion of patients with pheochromocytoma are detected before the development of symptoms. About $10 \%$ of catecholamine-producing tumors are located outside the adrenals - mostly found in the vicinity of the adrenals and the organ of Zuckerkandl. Extra-adrenal tumors occur, though more rarely, also in the pelvis adjacent to the rectum, vagina or bladder; contractions of the bladder may indeed induce hypertensive crises. Tumors may also occur in the thorax, originating from the sympathetic chain or the mediastinal paraganglia (Turchini et al. 2018).

Pheochromocytomas have been found in patients in an age range of as young as age 4 to over 80 years of age, but the majority of tumors become symptomatic in midadulthood, during the 4 th or 5 th decades. Another feature observed in about $10 \%$ of patients is multifocal tumors, sometimes located in both adrenal glands, sometimes with both adrenal and extra-adrenal locations or with only extra-adrenal locations.

Metastatic pheochromocytomas are rare. About 10\% of intra-adrenal tumors metastasize in comparison to almost $40 \%$ of extra-adrenal sympathetic PGLs (Lloyd et al. 2017). Tumor histology is a poor predictor of metastatic potential and no scoring system is unequivocally accepted.
Current thinking is that all pheochromocytomas have some metastatic potential and the terms metastatic and non-metastatic pheochromocytoma are therefore preferred over the use of benign and malignant (Lloyd et al. 2017).

\section{Pheochromocytoma-associated syndromes and hereditary pheochromocytoma}

There are interesting patterns and variations in the leading features of the pheochromocytoma genetic syndromes. Prior to the advent of genetic testing, classic reports included (i) remarkable coincidences of several relatives with pheochromocytomas or (ii) patients where pheochromocytoma is but one component of the presentation, which includes other tumorous and nontumorous manifestations or (iii) pheochromocytoma in one member of a given family and a completely different apparently coincident symptomatic tumor in a relative. DNA analyses were introduced during the late 1980s and remain the key determinant in a given patient as to whether a pheochromocytoma is genetic (i.e., heritable) or not. This became particularly evident in patients under 18 years of age demonstrating germline mutations of the RET, VHL, NF1, SDHA, SDHB, SDHC and SDHD genes in $80 \%$ of such patients; the most frequently mutated genes are VHL followed by SDHB and SDHD (Bausch et al. 2014). The major characteristics of the ten so far well-described syndromes are shown in Tables 1 and 2 .

\section{Multiple endocrine neoplasia type 2}

DNA technology first linked genetic pheochromocytoma to the RET proto-oncogene (Mulligan et al. 1993). The gene is located on chromosome 10 (10q11.21) and contains 21 exons. Germline mutations in the RET protooncogene cause multiple endocrine neoplasia type 2

Table 1 Frequencies of clinical characteristics of pheochromocytomas/paragangliomas in patients with germline mutations in MAX, NF1, RET, SDHA, SDHB, SDHC, SDHD, VHL and TMEM127.

\begin{tabular}{|c|c|c|c|}
\hline Mutated gene & $\begin{array}{l}\text { Adrenal } \\
\text { tumors }\end{array}$ & $\begin{array}{l}\text { Head and neck } \\
\text { tumors }\end{array}$ & $\begin{array}{c}\text { Extra-adrenal retroperitoneal, } \\
\text { pelvic or thoracic tumors }\end{array}$ \\
\hline MAX & ++++ & $(+)$ & + \\
\hline$N F 1$ & ++++ & $(+)$ & + \\
\hline$R E T$ & ++++ & $(+)$ & $(+)$ \\
\hline SDHA & +++ & +++ & +++ \\
\hline$S D H B$ & +++ & +++ & +++ \\
\hline SDHC & + & ++++ & $(+)$ \\
\hline$S D H D$ & ++ & ++++ & ++ \\
\hline$V H L$ & ++++ & $(+)$ & ++ \\
\hline TMEM127 & ++++ & + & $(+)$ \\
\hline
\end{tabular}

\begin{tabular}{c}
$\begin{array}{c}\text { Multiple } \\
\text { tumors }\end{array}$ \\
\hline++++ \\
+++ \\
++++ \\
+ \\
++ \\
++ \\
++++ \\
++++ \\
+++
\end{tabular}

Family history in probands for components of the given syndrome

Frequency definitions: $++++=>50 \% ;+++=25-50 \% ;++=11-24 \% ;+=1-10 \% ;(+)=<1 \%$. 


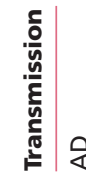

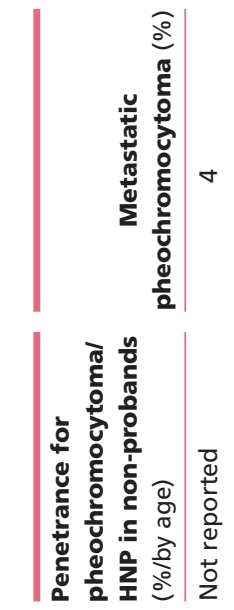

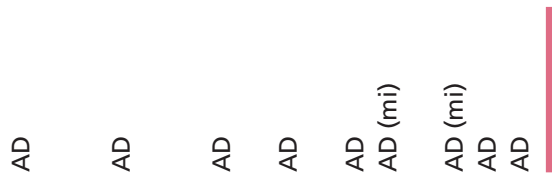

妾迹

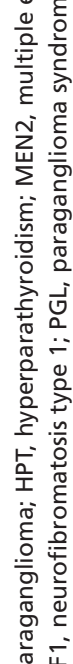

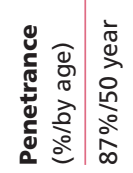

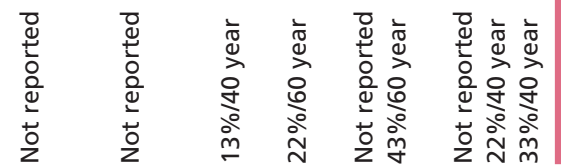

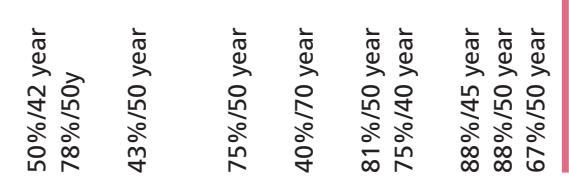

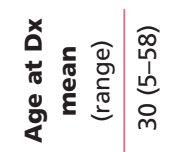

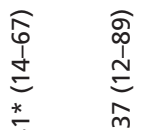

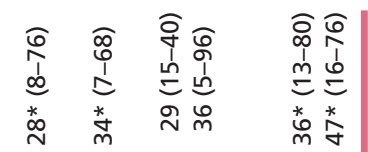

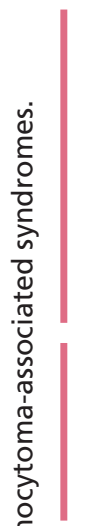
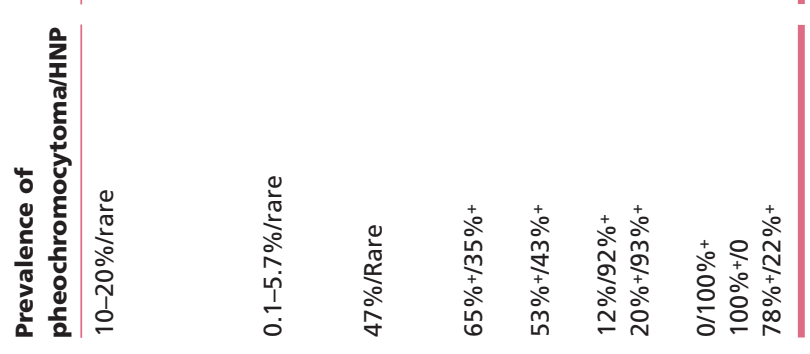

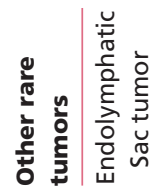

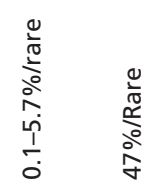

U্口ে

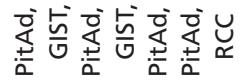

Чִ

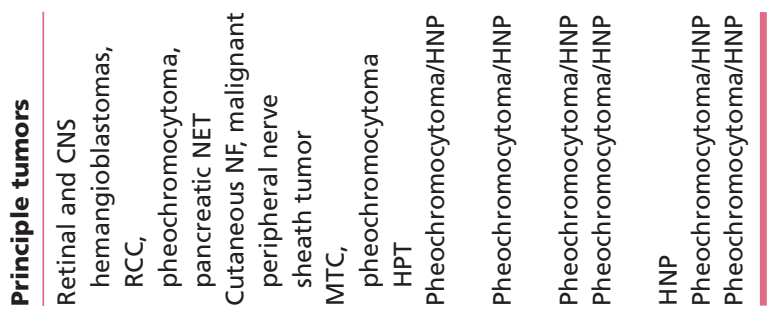

总

के

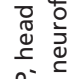

空㟧

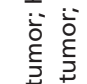

है

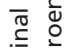

焉

点

0
0
0
0

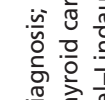

응

爻 亭高

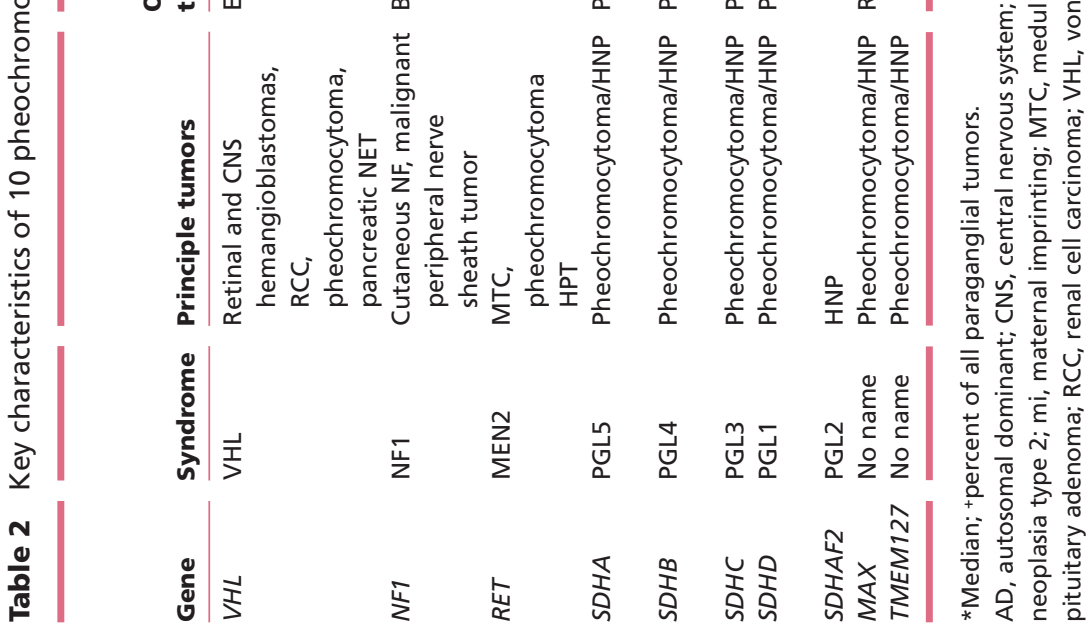


(MEN 2). The components of MEN 2 include medullary thyroid carcinoma (MTC) and pheochromocytoma. The prevalence is estimated to be approximately $1 / 40,000$. Clinical subtypes are MEN 2A with hyperparathyroidism and MEN 2B with cutaneous and skeletal anomalies. Mutations in only a few codons in the RET protooncogene, mainly located in exons 10, 11, 13, 14 and 16, predispose to MEN 2 (Eng et al. 1995, 1996, Gimm et al. 1997). The largest known population-based registry, with 1210 patients with MEN 2, was published in 2014 (Castinetti et al. 2014). Pheochromocytoma was detected in $563(47 \%)$ patients: 54\% developed symptomatic pheochromocytoma after a prior diagnosis of MTC; in $30 \%$ pheochromocytoma was detected at the same time as MTC and in 16\% pheochromocytoma was diagnosed before MTC. Overall, 388 (69\%) of the 563 patients had symptomatic pheochromocytoma. Bilateral adrenal pheochromocytomas were identified in 61\% (Fig. 1); 50\% of these patients had unilateral pheochromocytoma by age 44 years and bilateral by age 61 years. Extra-adrenal pheochromocytoma occurred in only $1 \%$ of patients, all of which were located close to the adrenal glands. Only two patients $(0.4 \%)$ had metastatic pheochromocytomas. The germline RET mutations were all of the missense type and were mainly located in exons 10 (10\%), 11 (85\%) and 16 (5\%) of RET. Few other large cohorts have been reported over the last 5 years. Mucha et al. reported that the penetrance and age at diagnosis of pheochromocytoma were correlated with medullary thyroid carcinoma

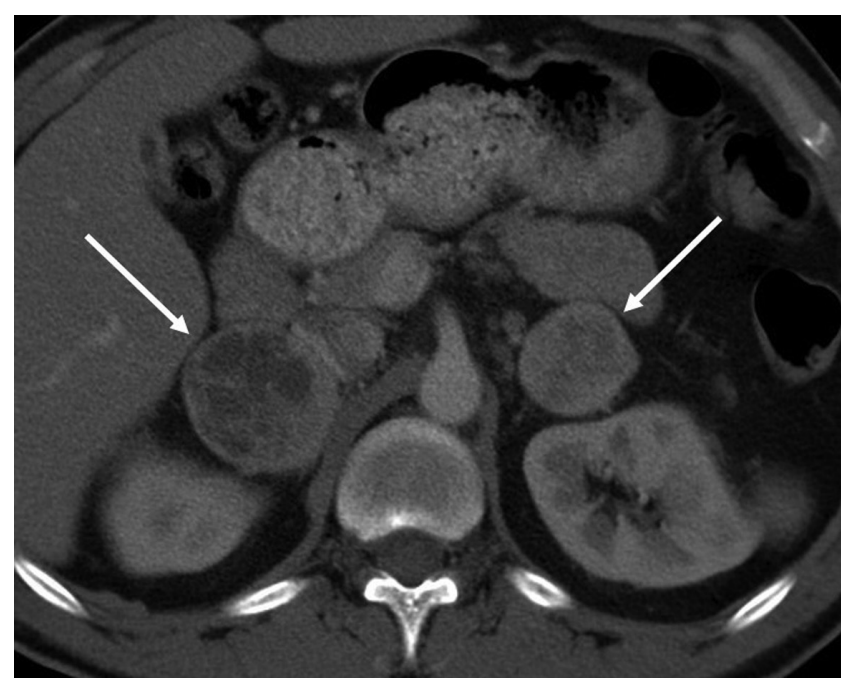

Figure 1

Axial image from an abdominal CT scan showing bilateral adrenal pheochromocytomas (arrows) in a 42-year-old patient with MEN 2. Following bilateral adrenalectomy, the patient has surgically induced Addison's disease. aggressiveness, and both correlated with RET mutation position: for instance, the penetrance was estimated at $47 \%$ in RET exon 11 vs 30\% in exon 10 carriers (Mucha et al. 2017). Castinetti et al. showed that even in RET codon 634 mutation (the most highly penetrant) carriers, the penetrance could be highly variable depending on the geographical area of the patient's origin, suggesting the roles of yet-unknown modifiers (Castinetti et al. 2017), while Siqueira et al. showed that RET polymorphisms had a modifying effect on the age at pheochromocytoma diagnosis (Siqueira et al. 2014). Of note, despite the fact that pheochromocytoma can be quite frequent in $R E T$ mutation carriers, Thosani et al. emphasized the lack of increased mortality in RET mutation carriers regularly screened for pheochromocytoma (Thosani et al. 2013).

\section{Von Hippel-Lindau disease}

VHL is characterized by tumors in more than 6 organs and include retinal hemangioblastomas (von Hippel disease) and hemangioblastomas of the central nervous system (CNS), mainly in the cerebellum (Lindau disease); renal clear cell cancer (RCC); pheochromocytoma; pancreatic neuroendocrine tumors; endolymphatic sac tumors of the inner ear and cysts and cystadenomas of the pancreas, epididymis and broad ligament (Lonser et al. 2003). The VHL gene is located on chromosome 3 (3p25-26) and contains 3 exons (Latif et al. 1993). The germline mutations are distributed over the whole VHL gene, although hot spots are found at codons 167 and 161. A broad spectrum of mutations has been observed, including missense, nonsense, intra-exonic insertions and deletions, splice site and large deletions and rearrangements (Zbar et al. 1996). Missense mutations are the most frequent cause of VHLassociated with pheochromocytoma. VHL was especially interesting from the RCC perspective and the fact that the most frequently observed sporadic form of RCC shows somatic mutations of the VHL gene, thus uncovering the etiology and pathogenesis (Gnarra et al. 1994).

A recent country-wide study from Denmark showed a prevalence of VHL of $1 / 46,900$, a birth incidence of $1 / 27,300$ and a penetrance of $87 \%$ at age 60 years; of note, $20 \%$ mutation carriers were asymptomatic at age 60 years (Binderup et al. 2017a). Estimated life expectancies of VHL patients born in 2000 are 67 years for males and 60 for females; CNS hemangioblastoma was the dominate cause of death (Binderup et al. 2017b). In the Freiburg-VHL-Registry that includes 265 VHL patients with pheochromocytomas, the tumor was symptomatic in $77 \%$ of the patients, and the most frequent 
pheochromocytoma was the dominating or even only manifestation of (Bender et al. 2001). Extra-adrenal and multiple, often bilateral, adrenal pheochromocytomas are not infrequent in VHL (Table 1) (Bausch et al. 2014, Aufforth et al. 2015), but thoracic paraganglial tumors and HNPs are very rare (Fig. 2). Overall, $51 \%$ of the patients had more than one paraganglial tumor, and $87 \%$ of these patients had their tumor detected by age 50 years. Only $4 \%$ of the patients had metastatic pheochromocytomas (Table 1). Of note, $55 \%$ of the patients had exclusively paraganglial tumors. Calculated optimal surveillance intervals for pheochromocytomas in VHL are about 4 years but shorter for other VHL-associated tumors (Kruizinga et al. 2014) and clinical investigations for VHLassociated pheochromocytomas are recommended to be initiated at an age of 5 years (Aufforth et al. 2015).

\section{Neurofibromatosis type 1}

The two largest reported series for neurofibromatosis type 1 (NF 1)-associated pheochromocytoma are the Freiburg International NF 1 pheochromocytoma study and the Mayo Clinic pheochromocytoma and PGL registry (Bausch et al. 2006, Gruber et al. 2017). Only $2 \%$ of patients in the Freiburg study, and $1.2 \%$ of patients in the Mayo Clinic registry, have symptomatic paraganglial tumors and NF 1 . Other NF 1 patient registries report pheochromocytomas in $0.1-5.7 \%$ of NF 1 patients (Gutmann et al. 1997, Gruber et al. 2017). Thus, NF 1-related pheochromocytomas are relatively uncommon.

Of the patients with NF 1 and pheochromocytoma in the Freiburg and Mayo registries, respectively, all except one patient had adrenal tumors. Bilateral adrenal tumors

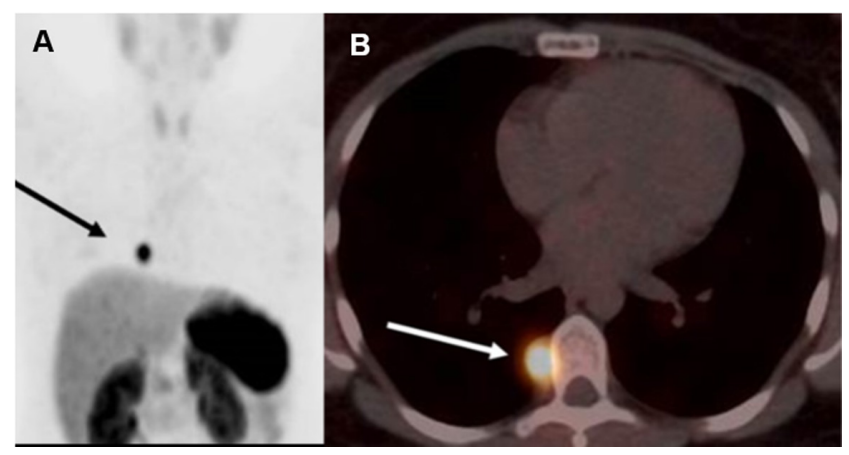

Figure 2

Imaging studies showing a thoracic paravertebral pheochromocytoma (arrows) in a 25-year-old woman with VHL. (A) Coronal maximumintensity projection of $\left[{ }^{68} \mathrm{Ga}\right]$ DOTATATE-PET/CT. (B) Axial fused image. The paravertebral tumor was removed by endoscopic surgery. were present in $25 \%$ and $17 \%$, respectively. Extra-adrenal paraganglial tumors were detected in only 2 patients from both registries. Metastatic pheochromocytomas were found in $7 \%$ of the patients in the two databases. In the Freiburg registry, $50 \%$ of the NF 1 patients with pheochromocytoma had such tumors by age 42 years and $78 \%$ by age 50 years. In the Mayo registry, the median age at pheochromocytoma diagnosis was 41 years (range, 14-67), although 4 patients were aged 21 years or younger.

In the Freiburg registry, all patients had multiple cutaneous neurofibromas, and other observed tumors included breast cancer, lung cancer and medullary thyroid cancer, each in one different individual. Only $27 \%$ of the patients had a family history for NF 1 and in only one case was a pheochromocytoma known in a relative. The detected mutations were missense mutations in $16 \%$, nonsense mutations in $22 \%$, frameshift mutations in $32 \%$, splice site in $20 \%$ and large deletions/rearrangements in $10 \%$ of patients, but without detection of NF 1 mutations in apparently sporadic pheochromocytomas (Bausch et al. 2006, 2007). However, more recently, a case with sporadic pheochromocytoma and a NF1 germline mutation has shown that 'dogmas' may have exceptions (Gieldon et al. 2018).

\section{Paraganglioma syndromes type 1-5}

The PGL syndromes (PGLs) were characterized over the decade from 2000 to 2010 (Baysal et al. 2000, Niemann \& Muller 2000, Astuti et al. 2001, Hao et al. 2009, Bayley et al . 2010, Burnichon et al. 2010). All five syndromes are associated with mutations that affect genes encoding subunits of the enzyme succinate dehydrogenase (SDH). The term PGL syndromes was introduced when the first detected susceptibility gene (SDHD, PGL1) was found in families with head and neck PGLs (HNPs) (Baysal et al. 2000). Another family with exclusively HNPs was described by van Baars et al. in 1982, but the gene SDHAF2 was not identified until 2010 and is now referred to as PGL2 (van Baars et al. 1982, Bayley et al. 2010). The PGL3 syndrome is caused by mutations of SDHC, PGL4 by mutations in SDHB and PGL5 by mutations in SDHA. Studies of patients with paraganglial tumors at other locations revealed that retroperitoneal, pelvic and thoracic paraganglial tumors also showed germline mutations of any of the SDH genes (SDHx). Germline mutations in one of the SDH genes, especially the $S D H D$ and $S D H B$ gene, are found in $8-10 \%$ of hereditary pheochromocytoma and HNP (Neumann et al. 2002, Curras-Freixes et al. 2015). 
PGL1-PGL5 are transmitted autosomal dominantly, but in PGL1 and PGL2 tumors (although fewer families have been described with PGL2 vs PGL1) virtually never occur in mutation carriers who inherited the mutation from their mothers (maternal imprinting). The key information is presented in Table 2 .

\section{Paraganglioma syndrome type 1 (SDHD)}

The SDHD gene is located on chromosome 11 (11q23) and contains 4 exons. Germline mutations are broadly distributed across the SDHD gene. So far, only one founder mutation has been described: p.Asp92Tyr (Hensen et al. 2012). So far, 148 disease-causing mutations associated with PGL syndrome type 1 have been described in the literature. A broad spectrum of mutations is observed: $25 \%$ missense, $14 \%$ nonsense, $41 \%$ small insertions and/or deletions, $7 \%$ variants affecting splicing and $13 \%$ large deletions and rearrangements (https://databases. lovd.nl/shared/genes/SDHD). Family pedigrees show that patients who inherit the mutation from their mothers almost never develop pheochromocytomas or HNPs (Taschner et al. 2001, Neumann \& Erlic 2008, Burnichon et al. 2017). HNPs and multifocal tumors characterize PGL1. Pheochromocytoma are less frequently observed (Neumann et al. 2004, Schiavi et al. 2005, Benn et al. 2006, Ricketts et al. 2010). The life-time penetrance is high with manifestation of the disease in $75 \%$ of the mutation carriers at age 40 years (Benn et al. 2006). Recent data for non-probands showed a penetrance of $43 \%$ at age 60 years (Andrews et al. 2018).

In the Freiburg International Registry and the French study (Burnichon et al. 2009, Neumann 2018), a total of 284 subjects were included. HNPs were present in 93\% of the patients and extra-adrenal or thoracic tumors in $20 \%$. Multiple tumors were detected in $68 \%$ of the patients, and metastatic disease in $5 \%$ of the patients. The range of age at diagnosis was 5-96, mean 36 years. A single paraganglial tumor without a family history was observed in about $30 \%$ of mutation carriers. Tumors outside the paraganglia are rare in PGL1. These include RCC (Casey et al. 2017b), pituitary adenomas (Ricketts et al. 2010, Xekouki \& Stratakis 2012, Evenepoel et al. 2015, Xekouki et al. 2015) and gastrointestinal stromal tumors (GISTs) (Pasini et al. 2008, Miettinen \& Lasota 2013).

\section{Paraganglioma syndrome type 2 (SDHAF2)}

PGL2 is caused by germline mutations of the SDHAF2 gene (Hao et al. 2009), which is located on chromosome
11 (11q13) and contains 4 exons. Similarly to SDHD and unlike other SDH genes, patients who inherit the mutation from their mothers do not develop pheochromocytomas or HNPs. Only 37 patients have been described, which include 34 from the same large Dutch pedigree (Hensen \& Bayley 2011). A separate but unrelated Spanish family has also been identified (Bayley et al. 2010, Kunst et al. 2011, Casey et al. 2014, Curras-Freixes et al. 2015, Bausch et al. $2017 a$ ). So far, only five mutations have been reported in the literature (https://databases.lovd.nl/shared/genes/ SDHAF2). All patients with bona fide pathogenic mutations show HNPs, typically multiple carotid body tumors. Three patients with unilateral adrenal pheochromocytoma have been described, but all carried relatively common SNPs that are unlikely to be related to disease. But of note, clinical characteristics and the mode of inheritance are based on only a very limited number of index cases and families.

\section{Paraganglioma syndrome type 3 (SDHC)}

PGL3 is caused by germline mutations of the SDHC gene, which is located on chromosome 1 (1q23.3) and contains 6 exons. A mutation hot spot at p.Arg133Ter has been described; otherwise, germline mutations are randomly distributed over the SDHC gene (Bourdeau et al. 2016). Thus far, 46 disease-causing mutations have been published: $39 \%$ missense, $13 \%$ nonsense, $15 \%$ small insertions and/or deletions, $11 \%$ variants affecting splicing and $22 \%$ large deletions and rearrangements (https://databases.lovd.nl/shared/genes/SDHC). Pooling of the clinical data from the Freiburg-InternationalPheochromocytoma-Paraganglioma-Registry (Neumann 2018), the Ann Arbor study (Else et al. 2014) and the French study (Burnichon et al. 2009) together include 61 patients. HNPs were present in $92 \%$ of the patients, mostly carotid body tumors. Four percent of the patients had retroperitoneal tumors and $8 \%$ had thoracic tumors. Multiple paraganglial tumors were detected in $25 \%$ of the patients, but none had a metastatic tumor. Eightyone percent of the patients had tumors by age 50 years. Of particular note, $87 \%$ of the patients showed HNPs exclusively. The majority of the patients had only a single tumor and no family history. Extra-paraganglial tumors in patients with SDHC germline mutations have been renal cell carcinoma in 4 cases (Malinoc et al. 2012, Ricketts et al. 2012, Gill et al. 2013, 2014) and GIST and pituitary adenoma in 1 case (Miettinen \& Lasota 2013, De Sousa et al. 2017). 


\section{Paraganglioma syndrome type 4 (SDHB)}

PGL4 is caused by mutations of the $S D H B$ gene, which is located on chromosome 1 (1p36.1-p35) and contains eight exons. Most germline mutations are randomly distributed over the $S D H B$ gene; only two hot spots have been described: SDHBc. $423+1 \mathrm{G}>\mathrm{A}$ and the Dutch founder large deletion in exon 3 (Bayley et al. 2009, Niemeijer et al. 2017). To date, 226 disease-causing mutations associated with PGL 4 have been described in the literature: $40 \%$ missense, $8 \%$ nonsense, $28 \%$ small insertions and/or deletions, $11 \%$ variants affecting splicing and 13\% large deletions/duplications (https://databases.lovd.nl/shared/ genes/SDHB). In contrast to PGL1, PGL4 is associated with pheochromocytomas, extra-adrenal thoracic or abdominal and metastatic tumors (Neumann et al. 2004, Benn et al. 2006, Ricketts et al. 2010). The Freiburg International and the French Registries (Burnichon et al. 2009, Neumann 2018) include 287 patients with $S D H B$ germline mutations. Of note, $53 \%$ had extra-adrenal retroperitoneal, pelvic and/or thoracic tumors and $43 \%$ had HNPs. Multiple tumors occurred in 13\% and metastatic tumors in $30 \%$ of the patients (Fig. 3). Age range at diagnosis was 8-78 years. Family history was positive for paraganglial tumors in 19\% of patients. The life-time penetrance is low with penetrance estimates of $20 \%$ by age 50 years and $40 \%$ by age 70 years (Jochmanova et al. 2017, Rijken et al. 2018). For genetic counseling, the penetrance of non-probands is of special interest and was reported as $22 \%$ by age 60 years (Andrews et al. 2018). Reported tumors outside the paraganglial system also included RCC (Vanharanta et al. 2004, Gill et al. 2014), GISTs (Miettinen \& Lasota 2013) and pituitary adenomas (Xekouki et al. 2015) rarely.

\section{Paraganglioma syndrome type 5 (SDHA)}

PGL5 is caused by germline mutations of the SDHA gene, which is located on chromosome 5 (5p15.33) and contains 15 exons. Two SDHA studies appeared in 2017, one from Freiburg, Germany and one from Cambridge, UK with 29 and 24 patients, respectively (Bausch et al. 2017a, Casey et al. 2017a). Thirty different disease-causing mutations, randomly distributed over the gene, have been described including 77\% missense, 10\% nonsense, $10 \%$ small insertions and/or deletions and 3\% variants affecting splicing. Tumor locations are adrenal in $24 \%$ and extra-adrenal retroperitoneal pheochromocytomas in $41 \%$ of patients. HNPs were present in $35 \%$ of the patients. Multiple paraganglial tumors were present in $11 \%$ of the patients, and $9 \%$ of the patients had a metastatic tumor. Age range at diagnosis was 12-66 years. Seventy-five percent of the patients had paraganglial tumors by age 50 years. Family history for a paraganglial tumor was positive in only $5 \%$ of the patients. Tumors observed outside the paraganglial system are rare and include RCC, GIST and pituitary adenoma (Miettinen \& Lasota 2013,

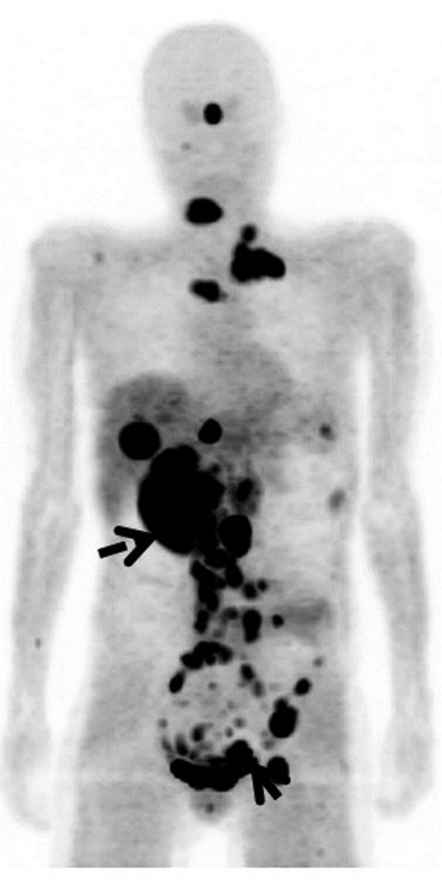

http://erc.endocrinology-journals.org https://doi.org/10.1530/ERC-18-0085
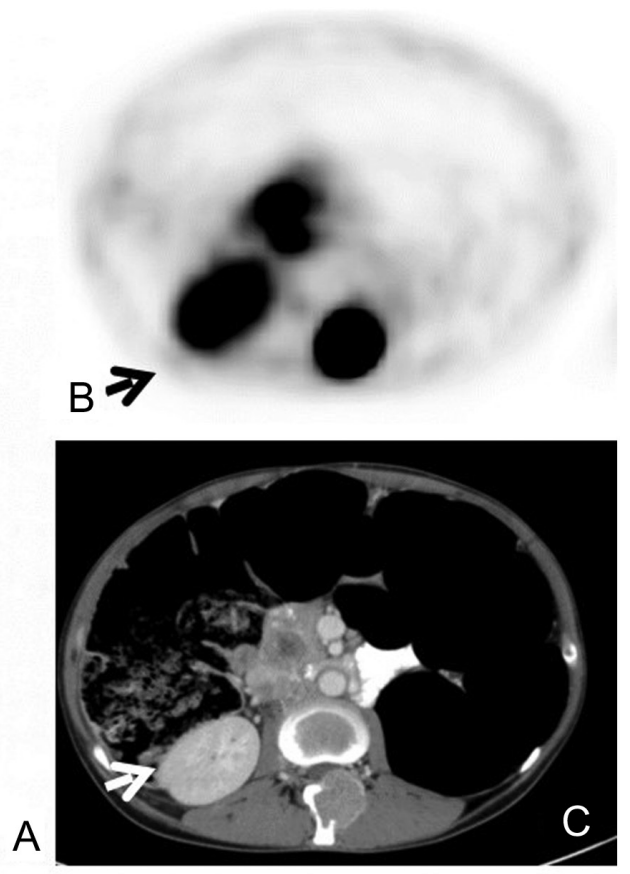

Figure 3

Metastatic pheochromocytoma in a 31-year-old woman with PGL4 (SDHB mutation). (A) Coronal maximum-intensity projection of [18F]fluorodopa-PET shows extensive metastatic spread with the only noteworthy physiological tracer uptake in the urinary bladder (lower arrow), the pituitary gland and the remaining right kidney (upper arrow). (B) Axial PET image showing two foci of metastatic pheochromocytoma and the right kidney (arrow). (C) Axial CT image corresponding to the axial PET image shows diffuse retroperitoneal disease and the remaining right kidney (arrow). 
Oudijk et al. 2013, Ozluk et al. 2015, Yakirevich et al. 2015). About $85 \%$ of the patients had only one paraganglial tumor and a negative family history.

\section{Hereditary pheochromocytoma syndrome associated with mutations in MAX}

Germline mutations of the MAX gene (MYC-associated factor X) cause pheochromocytoma and HNPs (CominoMendez et al. 2011). MAX is located on chromosome 14 (14q23.3) and contains 5 exons. Thus far, 58 cases have been described with 29 different germline mutations (Comino-Mendez et al. 2011, Burnichon et al. 2012, Rattenberry et al. 2013, Bausch et al. 2017a). Mutations include missense in 38\%, nonsense mutations in 46\% and splice site or frameshift mutations in $16 \%$ of patients. Adrenal tumor locations dominate and HNPs are very rare, whereas multifocal tumors are frequent. Metastatic tumors are also rare. Age range at diagnosis is 13-80 years; $88 \%$ of the patients had paraganglial tumors by age 50 years. Patients with a single paraganglial tumor and a negative family history were found in $36 \%$ of the mutation carriers.

\section{Hereditary pheochromocytoma syndrome associated with mutations in TMEM127}

Germline mutations of the TMEM127 gene (transmembrane protein 127) cause pheochromocytoma and HNP. TMEM127 is located on chromosome 2 (2q11.2) and contains four exons. Thus far, 100 cases have been described showing 40 different germline mutations (Qin et al. 2010, Yao et al. 2010, Abermil et al. 2012, Rattenberry et al. 2013, Casey et al. 2014, Welander et al. 2014, Curras-Freixes et al. 2015, Toledo et al. 2015, Patocs et al. 2016, Bausch et al. 2017a). Mutation types included $18 \%$ missense, $10 \%$ nonsense, $46 \%$ splice site and $18 \%$ frameshift mutations. Seventy percent of the mutation carriers had adrenal tumors, 5\% HNPs, $29 \%$ multifocal tumors and 3\% metastatic tumors. Age range at diagnosis was $16-76$ years; $67 \%$ of the patients had paraganglial tumors by age 50 years. Only one paraganglial tumor and a negative family history were found in only $39 \%$ of the mutation carriers. Tumors outside the paraganglia included RCC, malignant melanoma, colon cancer, pancreatic adenocarcinoma, acute myeloid leukemia and parathyroid adenoma, each in one patient (Hernandez et al. 2015, Bausch et al. 2017a).
Apparent hereditable pheochromocytoma syndrome associated with mutations in other susceptibility genes (FH, PHD1 and PHD2, MDH2, KIF1B $\beta$, HIF2alpha)

There are reports of germline mutations in additional susceptibility genes such as IDH (isocitrate dehydrogenase), HIF2A/EPAS1 (endothelial pas domain 1), FH (fumarate hydratase), PHD1 and PHD2 (prolyl hydroxylase domain proteins 1 and 2), $\mathrm{MDH} 2$ (malate dehydrogenase 2) and KIF1 $\beta$ (kinesin family member $1 \beta$ ). However, few of these genes currently appear to account for a considerable proportion of pheochromocytomas. Reported cases remain in the single digits for these genes. An example is mutations in $F H$, which were found in only 5 patients $(0.8 \%)$ with pheochromocytoma and HNP among 598 patients with disease-causing mutations (Letouze et al. 2013, Castro-Vega et al. 2014, Clark et al. 2014). For the PHD1 and PHD2 genes, one patient with PHD1 and two patients with PHD2 germline mutations have been identified (Welander et al. 2014, Yang et al. 2015). For the $M D H 2$ gene, a germline mutation was found in one patient with multiple malignant PGLs, and KIF1B $\beta$ germline mutations have been described in only four patients with pheochromocytoma (Schlisio et al. 2008, Yeh et al. 2008, Welander et al. 2014, Cascon et al. 2015). In addition, there are syndromes in which pheochromocytoma has been observed, however infrequently. The main example is multiple endocrine neoplasia type 1 .

\section{Summary of genetics of pheochromocytoma}

In 2014 , it was concluded that about $50 \%$ of patients with pheochromocytoma carry germline mutations (Fishbein et al. 2017, Toledo et al. 2017). Others have reported even higher percentages. A closer look at the Freiburg International PheochromocytomaParaganglioma-Registry suggests a figure of $35 \%$. It is important to note that following the identification of the 'major' genes, which include RET, VHL, SDHD, SDHB and $S D H C$, progress in terms of explaining further patients has been marginal, probably because any newly identified gene mutation is drawn from a pool of patient registries in which known genes have already been tested. We recently found germline mutations in SDHA, SDHAF2, MAX and TMEM127 in not more than $6 \%$ of such patients, representing 3\% of all subjects (Bausch et al. 2017a). Furthermore, all patients in our registry with a positive family history have now been diagnosed with germline mutations. 
The large number of pheochromocytoma susceptibility genes is an ideal challenge for new sequencing technologies in order to identify germline mutations. First reports of application of whole exome or whole genome sequencing are promising (Comino-Mendez et al. 2011, Crona et al. 2013, Rattenberry et al. 2013, Welander et al. 2014). An international consortium has recommended nextgeneration sequencing in the context of pheochromocytomas and HNPs (Toledo et al. 2017). Using these technologies is supposed not only to identify the mutations faster, but also to be less expensive. Larger studies will show whether we shall be confronted with limitations.

\section{Has genetics changed the diagnosis and management of pheochromocytoma?}

\section{Answer 1: Diagnosis and management of head and neck paragangliomas (HNPs)}

Up until the 2000, HNPs were considered to be rare lesions and were generally neglected by clinicians and scientists internationally. The identification of the $S D H D$ gene changed this scenario (Baysal et al. 2000). National and international HNP registries showed that HNPs are a constant and important manifestation in not only germline mutation carriers of $S D H D$, but also of $S D H B$, SDHC, SDHA and SDHAF2 (Fig. 4) (Neumann et al. 2004, Schiavi et al. 2005, Hao et al. 2009, Bausch et al. 2017a, Casey et al. 2017a). In parallel, patients initially presenting with abdominal tumors were diagnosed with HNPs as a co-manifestation. The genetics of pheochromocytoma emerged first to the scientific and soon after to the clinical otolaryngology community. At international meetings, the option of identification of germline mutation carriers and subsequent early diagnosis and treatment of HNPs is now discussed enthusiastically.

The main manifestations of carotid body tumors (CBTs) as well as jugular and tympanic PGLs must first be classified clinically, according to Shamblin for CBTs and to Fisch for jugulo-tympanic HNPs (Shamblin et al. 1971, Fisch \& Mattox 1988). While complete surgical resection represents the only curative treatment option for HNPs, multiple studies have demonstrated that complication rates after surgery were very much dependent on location and stage of the tumor (Suarez et al. 2013, 2014, 2015). CBTs in Shamblin class I and II, as well as tympanic PGLs, can usually be completely resected with a very low risk of morbidity and without mortality (Suarez et al. 2013, 2015). Tumor recurrence in this group of patients is very low. On the other hand, in patients with class III CBTs, vagal paragangliomas and jugular PGLs, intraoperative

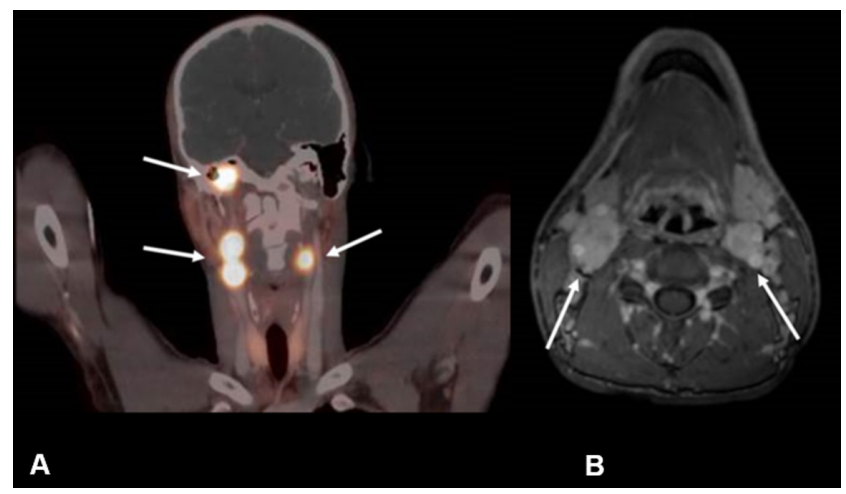

\section{Figure 4}

Multiple head and neck paragangliomas in a 24-year-old patient with PGL1 (SDHD mutation). (A) Coronal [ ${ }^{68 \mathrm{G} a}$ ] DOTATATE-PET/CT image showing bilateral carotid body tumors (lower arrows) and a right jugular paraganglioma (upper arrow). (B) Axial image of contrast-enhanced MRI shows bilateral enhancing carotid body tumors (arrows).

damage to major vessels and inferior cranial nerves is frequently seen (Suarez et al. 2013, 2014, 2015). Recurrent tumor growth is another problem frequently detected after surgical resection of jugular PGLs (Suarez et al. 2013, 2015). Of note, HNPs, including those diagnosed using the new genetic tools, are nearly always non-metastatic, noncatecholamine secreting and slowly growing (Suarez et al. 2015). Thus, multiple asymptomatic HNPs are not infrequently detected in newly recognized patients with SDHD mutations (PGL1); it seems to be wiser to decide not to operate but only to observe these HNPs. An exception to this indolent course is seen in carriers of $S D H B$ mutations; in the Freiburg-International-PheochromocytomaParaganglioma-Registry, there are 82 cases with $S D H B$ mutations and HNPs and, of these, 11 had metastatic paraganglial tumors, including 5 with HNP only and 6 subjects with an additional abdominal PGL. The discussion of whether surgery should be focused on CBTs Shamblin class I and II and tympanic HNPs is ongoing (Suarez et al. 2013, 2014, 2015). Stereotactic surgery and other forms of radiation therapy may be the treatment of choice for the majority of patients with jugular PGLs (Suarez et al. 2013, 2015). A wait-and-scan approach may be adequate for small asymptomatic HNPs and in patients with multiple HNPs. It is, however, important to emphasize that every patient with a HNP needs an individual therapeutic approach (Suarez et al. 2013, 2015). Important factors that have to be kept in mind include location; stage and size of the tumor; existing lower cranial nerve deficits and other clinical and psychologic impairments due to the tumor; age; general health condition of the patient; the presence of additional HNPs or other paraganglial tumors elsewhere in the body; genetic mutation with special emphasis on 
SDHB mutations and, last but not least, the preference of the patient.

\section{Answer 2: Clinical diagnosis of pheochromocytomas}

For each case of newly diagnosed pheochromocytoma, an interdisciplinary discussion raises the questions regarding which biochemical and imaging procedures are best and which ones are needed before surgery. Our interest in the genetics of pheochromocytoma inspired the only prospective investigation to study these questions, which was conducted in Freiburg (Neumann et al. 1993). All relevant methods available at that time were compared in a total of 42 newly diagnosed pheochromocytomas in 36 patients who all were later confirmed with mutations in $R E T$ or VHL. The primary findings showed very high diagnostic sensitivity for norepinephrine (86\%) and high sensitivity for MRI (95\%) (Neumann et al. 1993). Regarding biochemistry, subsequent studies demonstrated that 24-h urinary and also plasma normetanephrine is superior (but only marginally) to norepinephrine (Rao et al. 2017). We also learned that there are some differences regarding the proportion of metanephrine to normetanephrine excretion in carriers of mutations of different genes. Further, malignant pheochromocytoma can be associated with elevated methoxytyramine in the plasma (Peitzsch et al. 2013).

Regarding nuclear medicine imaging, we now recognize that $\left[{ }^{18} \mathrm{~F}\right]$ dihydroxyphenylalanine, $\left(\left[{ }^{18} \mathrm{~F}\right]\right.$ fluoro-dopa), $\left[{ }^{18} \mathrm{~F}\right]$ Fluorodopamine and ${ }^{68} \mathrm{Ga}$ ] DOTATATE PET CT/MRI are superior to 123- or 131-iodine-metaiodobenzylguanidine (MIBG) scintigraphy (Taieb et al. 2012, Rufini et al. 2013, Janssen et al. 2016).

For the key question of what is required before surgery, with advances in biochemistry and imaging, the answer that documentation of a clearly elevated fractionated catecholamine/metanephrine value combined with tumor localization by CT or MRI is sufficient, whereas nuclear-based imaging is optional.

\section{Answer 3: Treatment options}

Genetic predisposition to tumors results in specific geneinformed recommendations regarding treatment of diagnosed tumors and also includes considerations for prevention of potential tumor relapses or second tumors in the same organs. In terms of pheochromocytoma, curative treatment typically is adrenalectomy. However, as shown above, in genetic pheochromocytoma, bilateral adrenal tumors are frequent, and it needs to be emphasized that there may be a long interval until contralateral tumors become symptomatic and are detected. Thus, the adrenalectomy approach carries with it a high risk of surgically induced Addison's disease, and registry experiences indeed show that morbidity and mortality due to insufficient steroid replacement is more frequent than some would expect, because the deficiency was either not diagnosed or because patients were not compliant with their adrenal replacement program (Fig. 1). Adrenalsparing surgery was introduced in Germany for genetic pheochromocytoma even before germline mutation testing became available. The arguments in favor of this approach include long intervals to ipsilateral relapses, low malignancy risk and feasibility of reoperation. The adrenalsparing surgical approach is supported by recently reported experience for MEN 2-associated pheochromocytoma in a large study (Castinetti et al. 2014, 2016).

Progress in minimally invasive surgery technology and new genetic insights led in parallel to the concept of endoscopic adrenal-sparing treatment of genetic pheochromocytoma. Of note, endoscopic surgery is now also standard for extra-adrenal retroperitoneal pheochromocytoma and even a good option for pelvic and thoracic pheochromocytoma (Fig. 2) (Walz et al. 2006, 2018).

Progress in genetics for pheochromocytoma resulted in an enhanced referral of such patients to special treatment centers and a reconsideration of the accepted dogmas, for example the concept of alpha-adrenergic blockade for preoperative treatment of pheochromocytoma patients has been standard for several decades (Lenders et al. 2014). Alpha-adrenergic blockade cannot reliably prevent intraoperative hypertensive episodes, and despite alphaadrenergic blockade, many reports of intraoperative blood pressure increases above $200 \mathrm{mmHg}$ have been reported. Furthermore, and of special note, patients under alphaadrenergic blockade may develop significantly more perioperative hypotensive episodes. Moreover, the time needed for titration of the alpha-adrenergic blockade prior to surgery delays surgery and the final cure. The center in Essen recently reported 182 surgical procedures for pheochromocytoma completed without alpha-adrenergic blockade and free of any complications (Groeben et al. 2017). This new strategy of preoperative treatment continues to be under discussion.

In parallel to the advances in genetics, therapy of metastatic pheochromocytoma was strengthened by the introduction of radionuclide therapy, in which the coupling of the noradrenaline analogue MIBG to the cytotoxic beta-emitter iodine-131 allowed specific irradiation of neuroectodermal tumor tissue (Giammarile et al. 2008, Carrasquillo et al. 2016, Kong et al. 2017). 


\section{Answer 4: Histopathology}

The genetics of pheochromocytoma has also affected histopathology. The pathologist may play an expanded role in detection of apparently sporadic tumors with an occult hereditary basis. Furthermore, as all pheochromocytomas are now thought to have some metastatic potential, the classic binary approach to classification as either benign or malignant is being replaced by risk stratification. In keeping with this new thinking, the 2017 WHO classification replaces the terms benign and malignant with non-metastatic and metastatic, thereby avoiding confusion that historically resulted from competing definitions of malignancy (Tischler 2008, Lloyd et al. 2017). Although no formal histologic grading system for pheochromocytomas and PGLs is currently endorsed or universally applied, two systems, Pheochromocytoma of the Adrenal Gland Scaled Score (PASS) and Grading system for Adrenal Pheochromocytoma and Paraganglioma (GAPP), with overlapping histological parameters have been proposed (Thompson 2002, Kimura et al. $2014 a$ ). Categories of adverse features associated with metastatic tumors in both systems include invasion (vascular, capsular, periadrenal), necrosis, proliferative activity and diffuse growth or small cell size (Tischler \& deKrijger 2015). However, so far, there is no consensus on histological criteria for risk stratification in pathology reports. Currently, the chief risk factor for metastasis is the presence of a $S D H B$ mutation.

Insight into the genetic basis of pheochromocytomas and HNPs has led to the development of new immunohistochemical tools for pathologists, who in turn can now use immunohistochemistry as a guide for genetic testing or, if necessary, as a surrogate test (Fig. 5). Immunoreactivity for $S D H B$ is lost in all tumors that are SDH deficient (Dahia et al. 2005, van Nederveen et al. 2009). SDHA-deficient tumors are negative for SDHA (Papathomas et al. 2015, Korpershoek et al. 2016). MAX antibodies are now also available and often show loss of staining in tumors with mutations of the MAX gene (Korpershoek et al. 2016). In order for a case to be interpreted as negative for any of these markers, positive staining in endothelial cells must be seen as an internal control (Fig. 5E) (Kimura et al. 2014b).

\section{Answer 5: Referral centers and long-term care}

Patients with hereditary tumors need regular long-term care. Centers for rare diseases have been developed in large (usually university) hospitals. For hereditary pheochromocytomas, one center for around 20 million

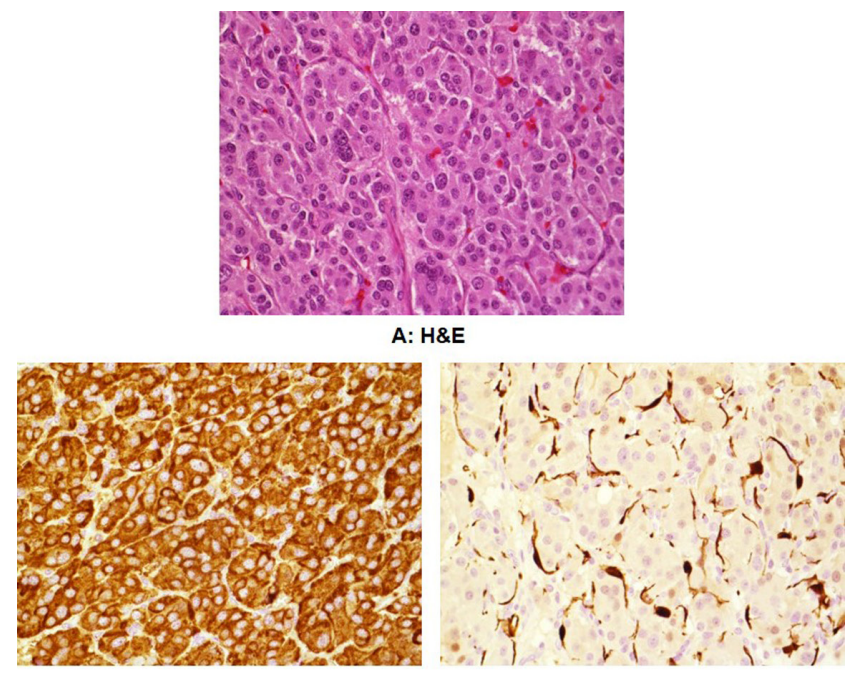

B+C: Chromogranin A - left - and S-100 - right

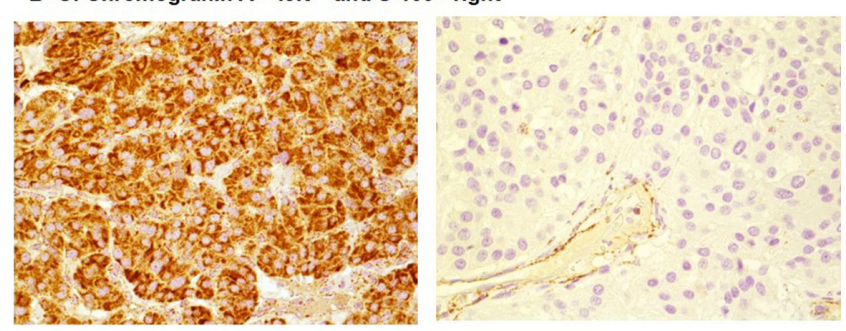

D+E: SDHB positive (left) and negative (right)

Figure 5

Histopathology and immunohistochemistry of pheochromocytoma. (A) H\&E staining showing typical prominent uniform cell nests (Zellballen). (B) Diffuse immunohistochemical staining for chromogranin A. (C) Immunohistochemical stain for S-100 showing typical distribution of sustentacular cells. (D) Positive $S D H B$ immunohistochemical staining. (E) Negative $S D H B$ immunohistochemical staining.

inhabitants seems to be sufficient. The investigations and reinvestigations by biochemistry and imaging procedures for these mostly young and working patients should be consolidated to one day and the test results and the options for treatment should be explained whenever possible the same day or by phone later. In particular, patients need psychological support when wait-andscan policies are suggested or a rare finding of metastases has to be discussed. In this context, information on pheochromocytoma and pheochromocytoma-associated syndromes prepared especially for patients and their relatives by us in 15 languages have been well accepted (www.prevention-medicine.com).

The referral centers should provide patients with information on specific risk profiles, including risks for offspring and risks associated with $S D H D / S D H A F 2$ maternal inheritance. A major hurdle is the costs, since insurance may not cover all aspects of the suggested programs, in 
particular, MRI and nuclear medicine imaging, especially in the case of non-approved PET tracers.

\section{Food for future thought}

The optimal surveillance strategy for families with a hereditary endocrine tumor syndrome is an ongoing point of discussion within multidisciplinary teams. The discussion is a balance between defining the age at which to start surveillance and surveillance intervals based on the calculation of the risk of developing a tumor (for instance, a risk of $<5 \%$ for missing a new manifestation) on the one hand (Kruizinga et al. 2014, Eijkelenkamp et al. 2017). On the other hand, surveillance recommendations may rest on the experience within a family with one exceptional family member - in all cases a child - who developed the tumor at a young age, leading to early and intensive surveillance. Another aspect is the lack of data regarding the behavior of a specific mutation within a family, or between individual to individual, as other biological characteristics or exposures may determine the behavior of a specific germline mutation. The above mentioned aspects are essential for the interpretation and application of international guidelines and make the counseling and support of these families a dedicated task.

\section{Declaration of interest}

The authors declare that there is no relevant conflict of interest.

\section{Funding}

This work did not receive any specific grant from any funding agency in the public, commercial or not-for-profit sector.

\section{Acknowledgements}

The authors are grateful to all the patients and families who have participated in our studies and registries, without whom key discoveries could not happen. They are also honored to have the privilege of caring for these patients and their families. C E is an American Cancer Society Clinical Research Professor and the Sondra J and Stephen R Hardis Endowed Chair of Cancer Genomic Medicine at the Cleveland Clinic. B Bausch and C Eng: shared senior authorship.

\section{References}

Abermil N, Guillaud-Bataille M, Burnichon N, Venisse A, Manivet P, Guignat L, Drui D, Chupin M, Josseaume C, Affres H,et al. 2012 TMEM127 screening in a large cohort of patients with pheochromocytoma and/or paraganglioma. Journal of Clinical Endocrinology and Metabolism 97 E805-E809. (https://doi. org/10.1210/jc.2011-3360)
Andrews KA, Ascher DB, Pires DEV, Barnes DR, Vialard L, Casey RT, Bradshaw N, Adlard J, Aylwin S, Brennan P,et al. 2018 Tumour risks and genotype-phenotype correlations associated with germline variants in succinate dehydrogenase subunit genes SDHB, SDHC and SDHD. Journal of Medical Genetics 55 384-394. (https://doi. org/10.1136/jmedgenet-2017-105127)

Astuti D, Latif F, Dallol A, Dahia PL, Douglas F, George E, Skoldberg F, Husebye ES, Eng C \& Maher ER 2001 Gene mutations in the succinate dehydrogenase subunit SDHB cause susceptibility to familial pheochromocytoma and to familial paraganglioma. American Journal of Human Genetics 69 49-54. (https://doi. org/10.1086/321282)

Aufforth RD, Ramakant P, Sadowski SM, Mehta A, Trebska-McGowan K, Nilubol N, Pacak K \& Kebebew E 2015 Pheochromocytoma screening initiation and frequency in von Hippel-Lindau syndrome. Journal of Clinical Endocrinology and Metabolism 100 4498-4504. (https://doi. org/10.1210/jc.2015-3045)

Bausch B, Borozdin W \& Neumann HP 2006 Clinical and genetic characteristics of patients with neurofibromatosis type 1 and pheochromocytoma. New England Journal of Medicine $\mathbf{3 5 4}$ 2729-2731. (https://doi.org/10.1056/NEJMc066006)

Bausch B, Borozdin W, Mautner VF, Hoffmann MM, Boehm D, Robledo M, Cascon A, Harenberg T, Schiavi F, Pawlu C,et al. 2007 Germline NF1 mutational spectra and loss-of-heterozygosity analyses in patients with pheochromocytoma and neurofibromatosis type 1 . Journal of Clinical Endocrinology and Metabolism 92 2784-2792. (https://doi.org/10.1210/jc.2006-2833)

Bausch B, Wellner U, Bausch D, Schiavi F, Barontini M, Sanso G, Walz MK, Peczkowska M, Weryha G, Dall'igna P,et al. 2014 Longterm prognosis of patients with pediatric pheochromocytoma. Endocrine-Related Cancer 21 17-25. (https://doi.org/10.1530/ERC-130415)

Bausch B, Schiavi F, Ni Y, Welander J, Patocs A, Ngeow J, Wellner U, Malinoc A, Taschin E, Barbon G,et al. 2017a Clinical characterization of the pheochromocytoma and paraganglioma susceptibility genes SDHA, TMEM127, MAX, and SDHAF2 for gene-informed prevention. JAMA Oncology 3 1204-1212. (https://doi.org/10.1001/ jamaoncol.2017.0223)

Bausch B, Tischler AS, Schmid KW, Leijon H, Eng C \& Neumann HPH $2017 b$ Max schottelius: pioneer in pheochromocytoma. Journal of the Endocrine Society 1 957-964. (https://doi.org/10.1210/js.2017-00208)

Bayley JP, Grimbergen AE, van Bunderen PA, van der Wielen M, Kunst HP, Lenders JW, Jansen JC, Dullaart RP, Devilee P, Corssmit EP,et al. 2009 The first Dutch SDHB founder deletion in paraganglioma-pheochromocytoma patients. BMC Medical Genetics 10 34. (https://doi.org/10.1186/1471-2350-10-34)

Bayley JP, Kunst HP, Cascon A, Sampietro ML, Gaal J, Korpershoek E, Hinojar-Gutierrez A, Timmers HJ, Hoefsloot LH, Hermsen MA,et al. 2010 SDHAF2 mutations in familial and sporadic paraganglioma and phaeochromocytoma. Lancet Oncology 11 366-372. (https://doi. org/10.1016/S1470-2045(10)70007-3)

Baysal BE, Ferrell RE, Willett-Brozick JE, Lawrence EC, Myssiorek D, Bosch A, van der Mey A, Taschner PE, Rubinstein WS, Myers EN,et al. 2000 Mutations in SDHD, a mitochondrial complex II gene, in hereditary paraganglioma. Science 287 848-851. (https:// doi.org/10.1126/science.287.5454.848)

Bender BU, Eng C, Olschewski M, Berger DP, Laubenberger J, Altehofer C, Kirste G, Orszagh M, van Velthoven V, Miosczka H,et al. 2001 VHL c.505 T>C mutation confers a high age related penetrance but no increased overall mortality. Journal of Medical Genetics $\mathbf{3 8}$ 508-514. (https://doi.org/10.1136/jmg.38.8.508)

Benn DE, Gimenez-Roqueplo AP, Reilly JR, Bertherat J, Burgess J, Byth K, Croxson M, Dahia PL, Elston M, Gimm O,et al. 2006 Clinical presentation and penetrance of pheochromocytoma/paraganglioma syndromes. Journal of Clinical Endocrinology and Metabolism 91 827-836. (https://doi.org/10.1210/jc.2005-1862)
(2) 2018 Society for Endocrinology Published by Bioscientifica Ltd. Printed in Great Britain 
Berends AMA, Buitenwerf E, de Krijger RR, Veeger N, van der HorstSchrivers ANA, Links TP \& Kerstens MN 2018 Incidence of pheochromocytoma and sympathetic paraganglioma in the Netherlands: a nationwide study and systematic review. European Journal of Internal Medicine 51 68-73. (https://doi.org/10.1016/j. ejim.2018.01.015)

Binderup ML, Galanakis M, Budtz-Jorgensen E, Kosteljanetz M \& Luise Bisgaard M 2017a Prevalence, birth incidence, and penetrance of von Hippel-Lindau disease (vHL) in Denmark. European Journal of Human Genetics 25 301-307. (https://doi.org/10.1038/ejhg.2016.173)

Binderup ML, Jensen AM, Budtz-Jorgensen E \& Bisgaard ML 2017b Survival and causes of death in patients with von Hippel-Lindau disease. Journal of Medical Genetics 54 11-18. (https://doi. org/10.1136/jmedgenet-2016-104058)

Bourdeau I, Grunenwald S, Burnichon N, Khalifa E, Dumas N, Binet MC, Nolet S \& Gimenez-Roqueplo AP 2016 A SDHC founder mutation causes paragangliomas (PGLs) in the French Canadians: new insights on the SDHC-related PGL. Journal of Clinical Endocrinology and Metabolism 101 4710-4718. (https://doi.org/10.1210/jc.2016-1665)

Burnichon N, Rohmer V, Amar L, Herman P, Leboulleux S, Darrouzet V, Niccoli P, Gaillard D, Chabrier G, Chabolle F,et al. 2009 The succinate dehydrogenase genetic testing in a large prospective series of patients with paragangliomas. Journal of Clinical Endocrinology and Metabolism 94 2817-2827. (https://doi.org/10.1210/jc.2008-2504)

Burnichon N, Briere JJ, Libe R, Vescovo L, Riviere J, Tissier F, Jouanno E, Jeunemaitre X, Benit P, Tzagoloff A,et al. 2010 SDHA is a tumor suppressor gene causing paraganglioma. Human Molecular Genetics 19 3011-3020. (https://doi.org/10.1093/hmg/ddq206)

Burnichon N, Cascon A, Schiavi F, Morales NP, Comino-Mendez I, Abermil N, Inglada-Perez L, de Cubas AA, Amar L, Barontini M,et al. 2012 MAX mutations cause hereditary and sporadic pheochromocytoma and paraganglioma. Clinical Cancer Research 18 2828-2837. (https://doi.org/10.1158/1078-0432.CCR-12-0160)

Burnichon N, Mazzella JM, Drui D, Amar L, Bertherat J, Coupier I, Delemer B, Guilhem I, Herman P, Kerlan V,et al. 2017 Risk assessment of maternally inherited SDHD paraganglioma and phaeochromocytoma. Journal of Medical Genetics 54 125-133. (https://doi.org/10.1136/jmedgenet-2016-104297)

Carrasquillo JA, Pandit-Taskar N \& Chen CC 2016 I-131 metaiodobenzylguanidine therapy of pheochromocytoma and paraganglioma. Seminars in Nuclear Medicine 46 203-214. (https:// doi.org/10.1053/j.semnuclmed.2016.01.011)

Cascon A, Comino-Mendez I, Curras-Freixes M, de Cubas AA, Contreras L, Richter S, Peitzsch M, Mancikova V, Inglada-Perez L, Perez-Barrios A,et al. 2015 Whole-exome sequencing identifies MDH2 as a new familial paraganglioma gene. Journal of the National Cancer Institute 107 djv053. (https://doi.org/10.1093/jnci/djv053)

Casey R, Garrahy A, Tuthill A, O'Halloran D, Joyce C, Casey MB, O'Shea P \& Bell M 2014 Universal genetic screening uncovers a novel presentation of an SDHAF2 mutation. Journal of Clinical Endocrinology and Metabolism 99 E1392-E1396. (https://doi. org/10.1210/jc.2013-4536)

Casey RT, Ascher DB, Rattenberry E, Izatt L, Andrews KA, Simpson HL, Challis B, Park SM, Bulusu VR, Lalloo F,et al. 2017a SDHA related tumorigenesis: a new case series and literature review for variant interpretation and pathogenicity. Molecular Genetics and Genomic Medicine 5 237-250. (https://doi.org/10.1002/mgg3.279)

Casey RT, Warren AY, Martin JE, Challis BG, Rattenberry E, Whitworth J, Andrews KA, Roberts T, Clark GR, West H,et al. 2017b Clinical and molecular features of Renal and Pheochromocytoma/Paraganglioma Tumor Association Syndrome (RAPTAS): case series and literature review. Journal of Clinical Endocrinology and Metabolism 102 4013-4022. (https://doi.org/10.1210/jc.2017-00562)

Castinetti F, Qi XP, Walz MK, Maia AL, Sanso G, Peczkowska M, HasseLazar K, Links TP, Dvorakova S, Toledo RA,et al. 2014 Outcomes of adrenal-sparing surgery or total adrenalectomy in phaeochromocytoma associated with multiple endocrine neoplasia type 2: an international retrospective population-based study. Lancet Oncology 15 648-655. (https://doi.org/10.1016/S14702045(14)70154-8)

Castinetti F, Taieb D, Henry JF, Walz M, Guerin C, Brue T, ConteDevolx B, Neumann HP \& Sebag F 2016 MANAGEMENT OF ENDOCRINE DISEASE: Outcome of adrenal sparing surgery in heritable pheochromocytoma. European Journal of Endocrinology $\mathbf{1 7 4}$ R9-R18.

Castinetti F, Maia AL, Peczkowska M, Barontini M, Hasse-Lazar K, Links TP, Toledo RA, Dvorakova S, Mian C, Bugalho MJ,et al. 2017 The penetrance of MEN2 pheochromocytoma is not only determined by RET mutations. Endocrine-Related Cancer 24 L63-L67. (https://doi.org/10.1530/ERC-17-0189)

Castro-Vega LJ, Buffet A, De Cubas AA, Cascon A, Menara M, Khalifa E, Amar L, Azriel S, Bourdeau I, Chabre O,et al. 2014 Germline mutations in FH confer predisposition to malignant pheochromocytomas and paragangliomas. Human Molecular Genetics 23 2440-2446. (https://doi.org/10.1093/hmg/ddt639)

Clark GR, Sciacovelli M, Gaude E, Walsh DM, Kirby G, Simpson MA, Trembath RC, Berg JN, Woodward ER, Kinning E, et al. 2014 Germline FH mutations presenting with pheochromocytoma. Journal of Clinical Endocrinology and Metabolism 99 E2046-E2050. (https:// doi.org/10.1210/jc.2014-1659)

Comino-Mendez I, Gracia-Aznarez FJ, Schiavi F, Landa I, LeandroGarcia LJ, Leton R, Honrado E, Ramos-Medina R, Caronia D, Pita G,et al. 2011 Exome sequencing identifies MAX mutations as a cause of hereditary pheochromocytoma. Nature Genetics 43 663-667. (https://doi.org/10.1038/ng.861)

Crona J, Verdugo AD, Granberg D, Welin S, Stalberg P, Hellman P \& Bjorklund P 2013 Next-generation sequencing in the clinical genetic screening of patients with pheochromocytoma and paraganglioma. Endocrine Connections 2 104-111. (https://doi.org/10.1530/EC-130009)

Curras-Freixes M, Inglada-Perez L, Mancikova V, Montero-Conde C, Leton R, Comino-Mendez I, Apellaniz-Ruiz M, Sanchez-Barroso L, Aguirre Sanchez-Covisa M, Alcazar V,et al. 2015 Recommendations for somatic and germline genetic testing of single pheochromocytoma and paraganglioma based on findings from a series of 329 patients. Journal of Medical Genetics 52 647-656. (https://doi.org/10.1136/jmedgenet-2015-103218)

Dahia PL, Ross KN, Wright ME, Hayashida CY, Santagata S, Barontini M, Kung AL, Sanso G, Powers JF, Tischler AS, et al. 2005 A HIF1alpha regulatory loop links hypoxia and mitochondrial signals in pheochromocytomas. PLoS Genetics 1 72-80.

De Sousa SM, McCabe MJ, Wu K, Roscioli T, Gayevskiy V, Brook K, Rawlings L, Scott HS, Thompson TJ, Earls P,et al. 2017 Germline variants in familial pituitary tumour syndrome genes are common in young patients and families with additional endocrine tumours. European Journal of Endocrinology 176 635-644. (https://doi. org/10.1530/EJE-16-0944)

Eijkelenkamp K, Osinga TE, de Jong MM, Sluiter WJ, Dullaart RP, Links TP, Kerstens MN \& van der Horst-Schrivers AN 2017 Calculating the optimal surveillance for head and neck paraganglioma in SDHB-mutation carriers. Familial Cancer 16 123-130. (https://doi.org/10.1007/s10689-016-9923-3)

Else T, Marvin ML, Everett JN, Gruber SB, Arts HA, Stoffel EM, Auchus RJ \& Raymond VM 2014 The clinical phenotype of SDHC-associated hereditary paraganglioma syndrome (PGL3). Journal of Clinical Endocrinology and Metabolism 99 E1482-E1486. (https://doi. org/10.1210/jc.2013-3853)

Elshafie O, Al Badaai Y, Alwahaibi K, Qureshi A, Hussein S, Al Azzri F, Almamari A \& Woodhouse N 2014 Catecholamine-secreting carotid body paraganglioma: successful preoperative control of hypertension and clinical symptoms using high-dose long-acting octreotide. Endocrinology, Diabetes and Metabolism Case Reports 2014140051. (c) 2018 Society for Endocrinology Published by Bioscientifica Ltd. Printed in Great Britain 
Eng C, Smith DP, Mulligan LM, Healey CS, Zvelebil MJ, Stonehouse TJ, Ponder MA, Jackson CE, Waterfield MD \& Ponder BA 1995 A novel point mutation in the tyrosine kinase domain of the RET protooncogene in sporadic medullary thyroid carcinoma and in a family with FMTC. Oncogene 10 509-513.

Eng C, Clayton D, Schuffenecker I, Lenoir G, Cote G, Gagel RF, van Amstel HK, Lips CJ, Nishisho I, Takai SI,et al. 1996 The relationship between specific RET proto-oncogene mutations and disease phenotype in multiple endocrine neoplasia type 2 . International RET mutation consortium analysis. JAMA 276 1575-1579. (https://doi. org/10.1001/jama.1996.03540190047028)

Evenepoel L, Papathomas TG, Krol N, Korpershoek E, de Krijger RR, Persu A \& Dinjens WN 2015 Toward an improved definition of the genetic and tumor spectrum associated with SDH germ-line mutations. Genetics in Medicine 17 610-620. (https://doi.org/10.1038/ $\operatorname{gim} .2014 .162)$

Fisch U \& Mattox D 1988 Microsurgery of the Skull Base, pp 149-153. Stuttgart, New York: Thieme.

Fishbein L, Leshchiner I, Walter V, Danilova L, Robertson AG, Johnson AR, Lichtenberg TM, Murray BA, Ghayee HK, Else T,et al. 2017 Comprehensive molecular characterization of pheochromocytoma and paraganglioma. Cancer Cell 31 181-193. (https://doi.org/10.1016/j.ccell.2017.01.001)

Giammarile F, Chiti A, Lassmann M, Brans B \& Flux G 2008 EANM procedure guidelines for 131I-meta-iodobenzylguanidine (131I-mIBG) therapy. European Journal of Nuclear Medicine and Molecular Imaging 35 1039-1047. (https://doi.org/10.1007/s00259008-0715-3)

Gieldon L, Masjkur JR, Richter S, Darr R, Lahera M, Aust D, Zeugner S, Rump A, Hackmann K, Tzschach A,et al. 2018 Next-generation panel sequencing identifies NF1 germline mutations in three patients with pheochromocytoma but no clinical diagnosis of neurofibromatosis type 1. European Journal of Endocrinology 178 K1-K9. (https://doi. org/10.1530/EJE-17-0714)

Gill AJ, Lipton L, Taylor J, Benn DE, Richardson AL, Frydenberg M, Shapiro J, Clifton-Bligh RJ, Chow CW \& Bogwitz M 2013 Germline SDHC mutation presenting as recurrent SDH deficient GIST and renal carcinoma. Pathology 45 689-691. (https://doi.org/10.1097/ PAT.0000000000000018)

Gill AJ, Hes O, Papathomas T, Sedivcova M, Tan PH, Agaimy A, Andresen PA, Kedziora A, Clarkson A, Toon CW,et al. 2014 Succinate dehydrogenase (SDH)-deficient renal carcinoma: a morphologically distinct entity: a clinicopathologic series of 36 tumors from 27 patients. American Journal of Surgical Pathology 38 1588-1602. (https://doi.org/10.1097/PAS.0000000000000292)

Gimm O, Marsh DJ, Andrew SD, Frilling A, Dahia PL, Mulligan LM, Zajac JD, Robinson BG \& Eng C 1997 Germline dinucleotide mutation in codon 883 of the RET proto-oncogene in multiple endocrine neoplasia type 2B without codon 918 mutation. Journal of Clinical Endocrinology and Metabolism 82 3902-3904. (https://doi. org/10.1210/jcem.82.11.4508)

Gnarra JR, Tory K, Weng Y, Schmidt L, Wei MH, Li H, Latif F, Liu S, Chen F, Duh FM,et al. 1994 Mutations of the VHL tumour suppressor gene in renal carcinoma. Nature Genetics 7 85-90. (https://doi.org/10.1038/ng0594-85)

Groeben H, Nottebaum BJ, Alesina PF, Traut A, Neumann HP \& Walz MK 2017 Perioperative alpha-receptor blockade in phaeochromocytoma surgery: an observational case series. British Journal of Anaesthesia 118 182-189. (https://doi.org/10.1093/bja/ aew392)

Gruber LM, Erickson D, Babovic-Vuksanovic D, Thompson GB, Young WF Jr \& Bancos I 2017 Pheochromocytoma and paraganglioma in patients with neurofibromatosis type 1. Clinical Endocrinology 86 141-149. (https://doi.org/10.1111/cen.13163)

Gutmann DH, Aylsworth A, Carey JC, Korf B, Marks J, Pyeritz RE, Rubenstein A \& Viskochil D 1997 The diagnostic evaluation and multidisciplinary management of neurofibromatosis 1 and neurofibromatosis 2. JAMA 278 51-57. (https://doi.org/10.1001/ jama.1997.03550010065042)

Hao HX, Khalimonchuk O, Schraders M, Dephoure N, Bayley JP, Kunst H, Devilee P, Cremers CW, Schiffman JD, Bentz BG,et al. 2009 SDH5, a gene required for flavination of succinate dehydrogenase, is mutated in paraganglioma. Science 325 1139-1142. (https://doi. org/10.1126/science.1175689)

Hensen EF \& Bayley JP 2011 Recent advances in the genetics of SDHrelated paraganglioma and pheochromocytoma. Familial Cancer 10 355-363. (https://doi.org/10.1007/s10689-010-9402-1)

Hensen EF, van Duinen N, Jansen JC, Corssmit EP, Tops CM, Romijn JA, Vriends AH, van der Mey AG, Cornelisse CJ, Devilee P,et al. 2012 High prevalence of founder mutations of the succinate dehydrogenase genes in the Netherlands. Clinical Genetics $\mathbf{8 1}$ 284-288. (https://doi.org/10.1111/j.1399-0004.2011.01653.x)

Hernandez KG, Ezzat S, Morel CF, Swallow C, Otremba M, Dickson BC, Asa SL \& Mete O 2015 Familial pheochromocytoma and renal cell carcinoma syndrome: TMEM127 as a novel candidate gene for the association. Virchows Archiv 466 727-732. (https://doi.org/10.1007/ s00428-015-1755-2)

Janssen I, Chen CC, Millo CM, Ling A, Taieb D, Lin FI, Adams KT, Wolf KI, Herscovitch P, Fojo AT,et al. 2016 PET/CT comparing (68) Ga-DOTATATE and other radiopharmaceuticals and in comparison with CT/MRI for the localization of sporadic metastatic pheochromocytoma and paraganglioma. European Journal of Nuclear Medicine and Molecular Imaging 43 1784-1791. (https://doi. org/10.1007/s00259-016-3357-x)

Jochmanova I, Wolf KI, King KS, Nambuba J, Wesley R, Martucci V, Raygada M, Adams KT, Prodanov T, Fojo AT,et al. 2017 SDHBrelated pheochromocytoma and paraganglioma penetrance and genotype-phenotype correlations. Journal of Cancer Research and Clinical Oncology 143 1421-1435. (https://doi.org/10.1007/s00432017-2397-3)

Kimura N, Takayanagi R, Takizawa N, Itagaki E, Katabami T, Kakoi N, Rakugi H, Ikeda Y, Tanabe A, Nigawara T,et al. 2014a Pathological grading for predicting metastasis in phaeochromocytoma and paraganglioma. Endocrine-Related Cancer 21 405-414. (https://doi. org/10.1530/ERC-13-0494)

Kimura N, Takekoshi K, Horii A, Morimoto R, Imai T, Oki Y, Saito T, Midorikawa S, Arao T, Sugisawa C,et al. 2014b Clinicopathological study of SDHB mutation-related pheochromocytoma and sympathetic paraganglioma. Endocrine-Related Cancer 21 L13-L16. (https://doi.org/10.1530/ERC-13-0530)

Kong G, Grozinsky-Glasberg S, Hofman MS, Callahan J, Meirovitz A, Maimon O, Pattison DA, Gross DJ \& Hicks RJ 2017 Efficacy of peptide receptor radionuclide therapy for functional metastatic paraganglioma and pheochromocytoma. Journal of Clinical Endocrinology and Metabolism 102 3278-3287. (https://doi. org/10.1210/jc.2017-00816)

Korpershoek E, Koffy D, Eussen BH, Oudijk L, Papathomas TG, van Nederveen FH, Belt EJ, Franssen GJ, Restuccia DF, Krol NM,et al. 2016 Complex MAX rearrangement in a family with malignant pheochromocytoma, renal oncocytoma, and erythrocytosis. Journal of Clinical Endocrinology and Metabolism 101 453-460. (https://doi. org/10.1210/jc.2015-2592)

Kruizinga RC, Sluiter WJ, de Vries EG, Zonnenberg BA, Lips CJ, van der Horst-Schrivers AN, Walenkamp AM \& Links TP 2014 Calculating optimal surveillance for detection of von Hippel-Lindau-related manifestations. Endocrine-Related Cancer 21 63-71. (https://doi. org/10.1530/ERC-13-0308)

Kunst HP, Rutten MH, de Monnink JP, Hoefsloot LH, Timmers HJ, Marres HA, Jansen JC, Kremer H, Bayley JP \& Cremers CW 2011 SDHAF2 (PGL2-SDH5) and hereditary head and neck paraganglioma. Clinical Cancer Research 17 247-254. (https://doi.org/10.1158/10780432.CCR-10-0420) 
Latif F, Tory K, Gnarra J, Yao M, Duh FM, Orcutt ML, Stackhouse T, Kuzmin I, Modi W, Geil L, et al. 1993 Identification of the von Hippel-Lindau disease tumor suppressor gene. Science $\mathbf{2 6 0}$ 1317-1320. (https://doi.org/10.1126/science.8493574)

Lenders JW, Duh QY, Eisenhofer G, Gimenez-Roqueplo AP, Grebe SK, Murad MH, Naruse M, Pacak K \& Young WF Jr 2014 Pheochromocytoma and paraganglioma: an endocrine society clinical practice guideline. Journal of Clinical Endocrinology and Metabolism 99 1915-1942. (https://doi.org/10.1210/jc.2014-1498)

Letouze E, Martinelli C, Loriot C, Burnichon N, Abermil N, Ottolenghi C, Janin M, Menara M, Nguyen AT, Benit P,et al. 2013 SDH mutations establish a hypermethylator phenotype in paraganglioma. Cancer Cell 23 739-752. (https://doi.org/10.1016/j. ccr.2013.04.018)

Lloyd RV, Osamura R, Klöppel G \& Rosai J Eds 2017 WHO Classifiaction of Tumours of Endocrine Organs. Lyon, France: IARC Press.

Lonser RR, Glenn GM, Walther M, Chew EY, Libutti SK, Linehan WM \& Oldfield EH 2003 von Hippel-Lindau disease. Lancet 361 2059-2067. (https://doi.org/10.1016/S0140-6736(03)13643-4)

Malinoc A, Sullivan M, Wiech T, Schmid KW, Jilg C, Straeter J, Deger S, Hoffmann MM, Bosse A, Rasp G,et al. 2012 Biallelic inactivation of the SDHC gene in renal carcinoma associated with paraganglioma syndrome type 3. Endocrine-Related Cancer 19 283-290. (https://doi. org/10.1530/ERC-11-0324)

Miettinen M \& Lasota J 2013 Gastrointestinal stromal tumors. Gastroenterology Clinics of North America 42 399-415. (https://doi. org/10.1016/j.gtc.2013.01.001)

Mucha L, Leidig-Bruckner G, Frank-Raue K, Bruckner T, Kroiss M \& Raue F 2017 Phaeochromocytoma in multiple endocrine neoplasia type 2: RET codon-specific penetrance and changes in management during the last four decades. Clinical Endocrinology 87 320-326. (https://doi.org/10.1111/cen.13386)

Mulligan LM, Kwok JB, Healey CS, Elsdon MJ, Eng C, Gardner E, Love DR, Mole SE, Moore JK, Papi L,et al. 1993 Germ-line mutations of the RET proto-oncogene in multiple endocrine neoplasia type $2 \mathrm{~A}$. Nature 363 458-460. (https://doi.org/10.1038/363458a0)

Neumann HP 2018 Pheochromocytoma. In JL Jameson, A Fauci, D Kasper, S Hauser, D Longo \& J Loscalzo. Harrison's Principles of Internal Medicine, 20th ed. New York, NY, USA: McGraw-Hill Professional.

Neumann HP \& Erlic Z 2008 Maternal transmission of symptomatic disease with SDHD mutation: fact or fiction? Journal of Clinical Endocrinology and Metabolism 93 1573-1575. (https://doi. org/10.1210/jc.2008-0569)

Neumann HP, Berger DP, Sigmund G, Blum U, Schmidt D, Parmer RJ, Volk B \& Kirste G 1993 Pheochromocytomas, multiple endocrine neoplasia type 2, and von Hippel-Lindau disease. New England Journal of Medicine 329 1531-1538. (https://doi.org/10.1056/ NEJM199311183292103)

Neumann HP, Bausch B, McWhinney SR, Bender BU, Gimm O, Franke G, Schipper J, Klisch J, Altehoefer C, Zerres K,et al. 2002 Germ-line mutations in nonsyndromic pheochromocytoma. New England Journal of Medicine 346 1459-1466. (https://doi.org/10.1056/ NEJMoa020152)

Neumann HP, Pawlu C, Peczkowska M, Bausch B, McWhinney SR, Muresan M, Buchta M, Franke G, Klisch J, Bley TA,et al. 2004 Distinct clinical features of paraganglioma syndromes associated with SDHB and SDHD gene mutations. JAMA 292 943-951. (https:// doi.org/10.1001/jama.292.8.943)

Niemann S \& Muller U 2000 Mutations in SDHC cause autosomal dominant paraganglioma, type 3. Nature Genetics 26 268-270. (https://doi.org/10.1038/81551)

Niemann S, Muller U, Engelhardt D \& Lohse P 2003 Autosomal dominant malignant and catecholamine-producing paraganglioma caused by a splice donor site mutation in SDHC. Human Genetics 113 92-94.
Niemeijer ND, Rijken JA, Eijkelenkamp K, van der Horst-Schrivers ANA, Kerstens MN, Tops CMJ, van Berkel A, Timmers H, Kunst HPM, Leemans CR,et al. 2017 The phenotype of SDHB germline mutation carriers: a nationwide study. European Journal of Endocrinology 177 115-125. (https://doi.org/10.1530/EJE-17-0074)

Oudijk L, Gaal J, Korpershoek E, van Nederveen FH, Kelly L, Schiavon G, Verweij J, Mathijssen RH, den Bakker MA, Oldenburg RA,et al. 2013 SDHA mutations in adult and pediatric wild-type gastrointestinal stromal tumors. Modern Pathology 26 456-463. (https://doi.org/10.1038/modpathol.2012.186)

Ozluk Y, Taheri D, Matoso A, Sanli O, Berker NK, Yakirevich E, Balasubramanian S, Ross JS, Ali SM \& Netto GJ 2015 Renal carcinoma associated with a novel succinate dehydrogenase A mutation: a case report and review of literature of a rare subtype of renal carcinoma. Human Pathology 46 1951-1955. (https://doi. org/10.1016/j.humpath.2015.07.027)

Papathomas TG, Oudijk L, Persu A, Gill AJ, van Nederveen F, Tischler AS, Tissier F, Volante M, Matias-Guiu X, Smid M,et al. 2015 SDHB/SDHA immunohistochemistry in pheochromocytomas and paragangliomas: a multicenter interobserver variation analysis using virtual microscopy: a Multinational Study of the European Network for the Study of Adrenal Tumors (ENS@T). Modern Pathology 28 807-821. (https://doi.org/10.1038/modpathol.2015.41)

Pasini B, McWhinney SR, Bei T, Matyakhina L, Stergiopoulos S, Muchow M, Boikos SA, Ferrando B, Pacak K, Assie G,et al. 2008 Clinical and molecular genetics of patients with the Carney-Stratakis syndrome and germline mutations of the genes coding for the succinate dehydrogenase subunits SDHB, SDHC, and SDHD. European Journal of Human Genetics 16 79-88. (https://doi.org/10.1038/sj. ejhg.5201904)

Patocs A, Lendvai NK, Butz H, Liko I, Sapi Z, Szucs N, Toth G, Grolmusz VK, Igaz P, Toth M,et al. 2016 Novel SDHB and TMEM127 mutations in patients with pheochromocytoma/paraganglioma syndrome. Pathology and Oncology Research 22 673-679. (https://doi. org/10.1007/s12253-016-0050-0)

Peitzsch M, Prejbisz A, Kroiss M, Beuschlein F, Arlt W, Januszewicz A, Siegert G \& Eisenhofer G 2013 Analysis of plasma 3-methoxytyramine, normetanephrine and metanephrine by ultraperformance liquid chromatography-tandem mass spectrometry: utility for diagnosis of dopamine-producing metastatic phaeochromocytoma. Annals of Clinical Biochemistry 50 147-155.

Pick L 1912 Das Ganglioma embryonale sympathicum (Sympathoma embryonale), eine typische bösartige Geschwulstform des sympathischen Nervensystems. Berliner Klinische Wochenschrift 49 $16-22$.

Qin Y, Yao L, King EE, Buddavarapu K, Lenci RE, Chocron ES, Lechleiter JD, Sass M, Aronin N, Schiavi F,et al. 2010 Germline mutations in TMEM127 confer susceptibility to pheochromocytoma. Nature Genetics 42 229-233. (https://doi.org/10.1038/ng.533)

Rao D, Peitzsch M, Prejbisz A, Hanus K, Fassnacht M, Beuschlein F, Brugger C, Fliedner S, Langton K, Pamporaki C,et al. 2017 Plasma methoxytyramine: clinical utility with metanephrines for diagnosis of pheochromocytoma and paraganglioma. European Journal of Endocrinology 177 103-113. (https://doi.org/10.1530/EJE-17-0077)

Rattenberry E, Vialard L, Yeung A, Bair H, McKay K, Jafri M, Canham N, Cole TR, Denes J, Hodgson SV,et al. 2013 A comprehensive next generation sequencing-based genetic testing strategy to improve diagnosis of inherited pheochromocytoma and paraganglioma. Journal of Clinical Endocrinology and Metabolism 98 E1248-1256. (https://doi.org/10.1210/jc.2013-1319)

Reeders ST, Breuning MH, Davies KE, Nicholls RD, Jarman AP, Higgs DR, Pearson PL \& Weatherall DJ 1985 A highly polymorphic DNA marker linked to adult polycystic kidney disease on chromosome 16 . Nature 317 542-544. (https://doi.org/10.1038/317542a0)

Ricketts CJ, Forman JR, Rattenberry E, Bradshaw N, Lalloo F, Izatt L, Cole TR, Armstrong R, Kumar VK, Morrison PJ,et al. 2010 Tumor 
risks and genotype-phenotype-proteotype analysis in 358 patients with germline mutations in SDHB and SDHD. Human Mutations 31 41-51. (https://doi.org/10.1002/humu.21136)

Ricketts CJ, Shuch B, Vocke CD, Metwalli AR, Bratslavsky G, Middelton L, Yang Y, Wei MH, Pautler SE, Peterson J,et al. 2012 Succinate dehydrogenase kidney cancer: an aggressive example of the warburg effect in cancer. Journal of Urology 188 2063-2071. (https://doi.org/10.1016/j.juro.2012.08.030)

Rijken JA, Niemeijer ND, Jonker MA, Eijkelenkamp K, Jansen JC, van Berkel A, Timmers H, Kunst HPM, Bisschop P, Kerstens MN, et al. 2018 The penetrance of paraganglioma and pheochromocytoma in SDHB germline mutation carriers. Clinical Genetics 93 60-66. (https://doi.org/10.1111/cge.13055)

Rufini V, Treglia G, Castaldi P, Perotti G \& Giordano A 2013 Comparison of metaiodobenzylguanidine scintigraphy with positron emission tomography in the diagnostic work-up of pheochromocytoma and paraganglioma: a systematic review. Quarterly Journal of Nuclear Medicine and Molecular Imaging 57 122-133.

Schiavi F, Boedeker CC, Bausch B, Peczkowska M, Gomez CF, Strassburg T, Pawlu C, Buchta M, Salzmann M, Hoffmann MM,et al. 2005 Predictors and prevalence of paraganglioma syndrome associated with mutations of the SDHC gene. JAMA 294 2057-2063. (https://doi.org/10.1001/jama.294.16.2057)

Schlisio S, Kenchappa RS, Vredeveld LC, George RE, Stewart R, Greulich H, Shahriari K, Nguyen NV, Pigny P, Dahia PL,et al. 2008 The kinesin KIF1Bbeta acts downstream from EgIN3 to induce apoptosis and is a potential 1p36 tumor suppressor. Genes and Development 22 884-893. (https://doi.org/10.1101/gad.1648608)

Shamblin WR, ReMine WH, Sheps SG \& Harrison EG Jr 1971 Carotid body tumor (chemodectoma). Clinicopathologic analysis of ninety cases. American Journal of Surgery 122 732-739. (https://doi. org/10.1016/0002-9610(71)90436-3)

Siqueira DR, Ceolin L, Ferreira CV, Romitti M, Maia SC, Maciel LM \& Maia AL 2014 Role of RET genetic variants in MEN2-associated pheochromocytoma. European Journal of Endocrinology 170 821-828. (https://doi.org/10.1530/EJE-14-0084)

Suarez C, Rodrigo JP, Bodeker CC, Llorente JL, Silver CE, Jansen JC, Takes RP, Strojan P, Pellitteri PK, Rinaldo A,et al. 2013 Jugular and vagal paragangliomas: systematic study of management with surgery and radiotherapy. Head and Neck 35 1195-1204. (https://doi. org/10.1002/hed.22976)

Suarez C, Rodrigo JP, Mendenhall WM, Hamoir M, Silver CE, Gregoire V, Strojan P, Neumann HP, Obholzer R, Offergeld C,et al. 2014 Carotid body paragangliomas: a systematic study on management with surgery and radiotherapy. European Archives of Oto-Rhino-Laryngology 271 23-34. (https://doi.org/10.1007/s00405-013-2384-5)

Suarez C, Fernandez-Alvarez V, Neumann HP, Boedeker CC, Offergeld C, Rinaldo A, Strojan P \& Ferlito A 2015 Modern trends in the management of head and neck paragangliomas. European Archives of Oto-Rhino-Laryngology 272 3595-3599. (https://doi.org/10.1007/ s00405-015-3793-4)

Taieb D, Timmers HJ, Hindie E, Guillet BA, Neumann HP, Walz MK, Opocher G, de Herder WW, Boedeker CC, de Krijger RR,et al. 2012 EANM 2012 guidelines for radionuclide imaging of phaeochromocytoma and paraganglioma. European Journal of Nuclear Medicine and Molecular Imaging 39 1977-1995. (https://doi. org/10.1007/s00259-012-2215-8)

Taschner PE, Jansen JC, Baysal BE, Bosch A, Rosenberg EH, BrockerVriends AH, van Der Mey AG, van Ommen GJ, Cornelisse CJ \& Devilee P 2001 Nearly all hereditary paragangliomas in the Netherlands are caused by two founder mutations in the SDHD gene. Genes, Chromosomes and Cancer 31 274-281. (https://doi. org/10.1002/gcc.1144)

Thompson LD 2002 Pheochromocytoma of the Adrenal gland Scaled Score (PASS) to separate benign from malignant neoplasms: a clinicopathologic and immunophenotypic study of 100 cases.
American Journal of Surgical Pathology 26 551-566. (https://doi. org/10.1097/00000478-200205000-00002)

Thosani S, Ayala-Ramirez M, Palmer L, Hu MI, Rich T, Gagel RF, Cote G, Waguespack SG, Habra MA \& Jimenez C 2013 The characterization of pheochromocytoma and its impact on overall survival in multiple endocrine neoplasia type 2. Journal of Clinical Endocrinology and Metabolism 98 E1813-E1819. (https://doi.org/10.1210/jc.2013-1653)

Tischler AS 2008 Pheochromocytoma and extra-adrenal paraganglioma: updates. Archives of Pathology and Laboratory Medicine 132 1272-1284.

Tischler AS \& deKrijger RR 201515 YEARS OF PARAGANGLIOMA: Pathology of pheochromocytoma and paraganglioma. EndocrineRelated Cancer 22 T123-T133. (https://doi.org/10.1530/ERC-15-0261)

Toledo SP, Lourenco DM Jr, Sekiya T, Lucon AM, Baena ME, Castro CC, Bortolotto LA, Zerbini MC, Siqueira SA, Toledo RA, et al. 2015 Penetrance and clinical features of pheochromocytoma in a sixgeneration family carrying a germline TMEM127 mutation. Journal of Clinical Endocrinology and Metabolism 100 E308-E318. (https://doi. org/10.1210/jc.2014-2473)

Toledo RA, Burnichon N, Cascon A, Benn DE, Bayley JP, Welander J, Tops CM, Firth H, Dwight T, Ercolino T,et al. 2017 Consensus statement on next-generation-sequencing-based diagnostic testing of hereditary phaeochromocytomas and paragangliomas. Nature Review Endocrinology 13 233-247. (https://doi.org/10.1038/nrendo.2016.185)

Turchini J, Cheung VKY, Tischler AS, De Krijger RR \& Gill AJ 2018 Pathology and genetics of phaeochromocytoma and paraganglioma. Histopathology 72 97-105. (https://doi.org/10.1111/his.13402)

van Baars F, Cremers C, van den Broek P, Geerts S \& Veldman J 1982 Genetic aspects of nonchromaffin paraganglioma. Human Genetics 60 305-309. (https://doi.org/10.1007/BF00569208)

van Nederveen FH, Gaal J, Favier J, Korpershoek E, Oldenburg RA, de Bruyn EM, Sleddens HF, Derkx P, Riviere J, Dannenberg H,et al. 2009 An immunohistochemical procedure to detect patients with paraganglioma and phaeochromocytoma with germline SDHB, SDHC, or SDHD gene mutations: a retrospective and prospective analysis. Lancet Oncology 10 764-771. (https://doi.org/10.1016/ S1470-2045(09)70164-0)

Vanharanta S, Buchta M, McWhinney SR, Virta SK, Peczkowska M, Morrison CD, Lehtonen R, Januszewicz A, Jarvinen H, Juhola M,et al. 2004 Early-onset renal cell carcinoma as a novel extraparaganglial component of SDHB-associated heritable paraganglioma. American Journal of Human Genetics 74 153-159. (https://doi. org/10.1086/381054)

Walz MK, Alesina PF, Wenger FA, Koch JA, Neumann HP, Petersenn S, Schmid KW \& Mann K 2006 Laparoscopic and retroperitoneoscopic treatment of pheochromocytomas and retroperitoneal paragangliomas: results of 161 tumors in 126 patients. World Journal of Surgery 30 899-908. (https://doi.org/10.1007/s00268-005-0373-6)

Walz MK, Iova LD, Deimel J, Neumann HPH, Bausch B, Zschiedrich S, Groeben H \& Alesina PF 2018 Minimally Invasive Surgery (MIS) in children and adolescents with pheochromocytomas and retroperitoneal paragangliomas: experiences in 42 patients. World Journal of Surgery 42 1024-1030. (https://doi.org/10.1007/s00268018-4488-y)

Welander J, Andreasson A, Juhlin CC, Wiseman RW, Backdahl M, Hoog A, Larsson C, Gimm O \& Soderkvist P 2014 Rare germline mutations identified by targeted next-generation sequencing of susceptibility genes in pheochromocytoma and paraganglioma. Journal of Clinical Endocrinology and Metabolism 99 E1352-E1360. (https://doi.org/10.1210/jc.2013-4375)

Xekouki P \& Stratakis CA 2012 Succinate dehydrogenase (SDHx) mutations in pituitary tumors: could this be a new role for mitochondrial complex II and/or Krebs cycle defects? EndocrineRelated Cancer 19 C33-C40. (https://doi.org/10.1530/ERC-12-0118)

Xekouki P, Szarek E, Bullova P, Giubellino A, Quezado M, Mastroyannis SA, Mastorakos P, Wassif CA, Raygada M,
(2) 2018 Society for Endocrinology Published by Bioscientifica Ltd. Printed in Great Britain 
Rentia N,et al. 2015 Pituitary adenoma with paraganglioma/ pheochromocytoma (3PAs) and succinate dehydrogenase defects in humans and mice. Journal of Clinical Endocrinology and Metabolism 100 E710-E719. (https://doi.org/10.1210/jc.2014-4297)

Yakirevich E, Ali SM, Mega A, McMahon C, Brodsky AS, Ross JS, Allen J, Elvin JA, Safran H \& Resnick MB 2015 A novel SDHA-deficient renal cell carcinoma revealed by comprehensive genomic profiling. American Journal of Surgical Pathology 39 858-863. (https://doi. org/10.1097/PAS.0000000000000403)

Yang C, Zhuang Z, Fliedner SM, Shankavaram U, Sun MG, Bullova P, Zhu R, Elkahloun AG, Kourlas PJ, Merino M,et al. 2015 Germ-line PHD1 and PHD2 mutations detected in patients with pheochromocytoma/paraganglioma-polycythemia. Journal of Molecular Medicine 93 93-104. (https://doi.org/10.1007/s00109-014-1205-7)

Yao L, Schiavi F, Cascon A, Qin Y, Inglada-Perez L, King EE, Toledo RA, Ercolino T, Rapizzi E, Ricketts CJ,et al. 2010 Spectrum and prevalence of FP/TMEM127 gene mutations in pheochromocytomas and paragangliomas. JAMA 304 2611-2619. (https://doi.org/10.1001/ jama.2010.1830)

Yeh IT, Lenci RE, Qin Y, Buddavarapu K, Ligon AH, Leteurtre E, Do Cao C, Cardot-Bauters C, Pigny P \& Dahia PL 2008 A germline mutation of the KIF1B beta gene on 1p36 in a family with neural and nonneural tumors. Human Genetics 124 279-285. (https://doi. org/10.1007/s00439-008-0553-1)

Zbar B, Kishida T, Chen F, Schmidt L, Maher ER, Richards FM, Crossey PA, Webster AR, Affara NA, Ferguson-Smith MA,et al. 1996 Germline mutations in the Von Hippel-Lindau disease (VHL) gene in families from North America, Europe, and Japan. Human Mutations 8 348-357. (https://doi.org/10.1002/(SICI)10981004(1996)8:4<348::AID-HUMU8>3.0.CO;2-3)

Zeng G, Feng H, Zhao J, Ma Y, Huang B \& Yang Y 2013 Clinical characteristics and strategy for treatment of functional carotid body tumours. International Journal of Oral and Maxillofacial Surgery $\mathbf{4 2}$ 436-439. (https://doi.org/10.1016/j.ijom.2012.09.023)

Received in final form 14 May 2018

Accepted 24 May 2018

Accepted Preprint published online 24 May 2018
(C) 2018 Society for Endocrinology Published by Bioscientifica Ltd. Printed in Great Britain 